Atıf/Citation: Duran Tekoğlu, A. \& Sığrı, Ü. (2020). Artırılmış gerçeklik ile pazarlamanın, tüketici deneyimi ve çevrimiçi satın alma niyeti ile ilişkisi üzerine nitel bir araştırma. Nitel Sosyal Bilimler, 2(2), 116-141.

\title{
Artırılmış Gerçeklik ile Pazarlamanın, Tüketici Deneyimi ve Çevrimiçi Satın Alma Niyeti ile İlişkisi Üzerine Nitel Bir Araştırma
}

\author{
${ }^{a}$ Aycan Duran Tekoğlu' ${ }^{1}$, b̈̈nsal Sığrı \\ ${ }^{a}$ Doktora Öğrencisi, Başkent Üniversitesi, Türkiye \\ ${ }^{b}$ Prof. Dr., Ostim Teknik Üniversitesi, Türkiye
}

$\ddot{O} z$

Artırılmış gerçeklik, çevrenin ve içindekilerin teknoloji ile buluşması yoluyla ortaya çıkan görüntülerin canlı, dinamik ve gerçek zamanlı olarak hissedilip yaşanmasını sağlamaktadır. Gerçek ortam üzerine grafik, ses ve diğer duyusal özellikler ekleyen artırılmış gerçeklik teknolojisi, tasarıları görselleştirmek ve çeşitli işlemler yapabilmek için endüstriyel tasarımda, tehditleri önceden saptayabilmek için savunma sektörü alanında, birçok oyun içeriklerinde, tüketicilere bir ürünün ambalajını daha açmadan içinde neyin olduğunu ön izleme firsatı sunan pazarlama alanında, mekânsal etkileşimlerde, montaj bakım gibi görev desteğinde ve inovatif ürünlerde kullanılmaya başlanmışırı.

$\mathrm{Bu}$ araştırmanın amacı, artırılmış gerçeklik teknolojisinin tüketici deneyimi ve çevrimiçi satın alma niyetine etkisini inceleyerek pazarlama alanındaki potansiyelini belirlemeye çalışmaktır. Çalışmada, bir olgunun nasıl algılandığına ve deneyimlendiğine ilişkin bir araştırma yürütüldüğü için nitel araştırma desenlerinden fenomenoloji yaklaşımı kullanılmıştır. Araştırma, yüz yüze derinlemesine görüşmeler yoluyla elde edilecek verileri toplamak için birebir mülakatlar, odak grup görüşmesi ve gözlem tekniklerinin kullanıldığı nitel bir çalışma üzerine temellendirilmiş̧ir. Araştırma kapsamında Ankara ilinde 6 tüketici ve bir firmadan 2 yetkiliyle birebir görüşmeler, 4 tüketici ile ise odak grup görüşmesi gerçekleştirilmiştir. Aynı zamanda uygulamanın daha ayrıntılı değerlendirilebilmesi için kullanıcı görüşlerinin yer aldığı internet forumları incelenmiştir. Elde edilen bulgular, nitel veri analizinde QDA Miner programı ile analiz edilmiştir. Yapılan araştırma 1şığında, artırılmış gerçeklik ile pazarlamanın, tüketici deneyimi ve çevrimiçi satın alma niyeti üzerinde etkili olduğu sonucuna varılmıştır. Yapılan mülakatlardan elde edilen sonuçlar katılımcıların uygulamayı ilk defa tecrübe ettiklerini göstermekle birlikte uygulamanın olumlu ve gelişmeye açık yönlerini ortaya koymaları, artırılmış gerçeklik teknolojisinin pazarlama açısından önemli bir potansiyele sahip olduğunu göstermektedir.

Anahtar Kelimeler: nitel araştırma, artırılmış gerçeklik, tüketici deneyimi, satın alma niyeti

\begin{tabular}{l}
$\begin{array}{l}{ }^{1} \text { Sorumlu Yazar/Corresponding Author: (iD) Aycan Duran Tekoğlu, Başkent Üniversitesi, duran.aycan@ gmail.com, Türkiye } \\
\text { Gönderim Tarihi/Received: } 22.09 .2020\end{array}$ Kabul Tarihi/Accepted: 12.11.2020 $\quad$ Yayımlanma Tarihi/Published: 31.12 .2020 \\
\hline
\end{tabular}

Telif hakkı: (C) 2020 Duran Tekoğlu \& Sığrı. Bu lisans, yazarın orijinal yaratıcı olarak atfedilmesi ve yeniden kullanımın ticari olmayan amaçlarla, yani araştırma veya eğitim amaçlı kullanımla sınırlı olması koşuluyla, kullanıcıların makaleyi kullanmasına, çoğaltmasına, yaymasına veya görüntülemesine izin verir.

Copyright: (C) 2020 Duran Tekoğlu \& Sığrı. This licence permits users to use, reproduce, disseminate or display the article provided that the author is attributed as the original creator and that the reuse is restricted to non-commercial purposes i.e. research or educational use. 


\title{
A Qualitative Study on the Relationships of Marketing via Augmented Reality with Consumer Experience and Online Purchase Intention
}

\author{
Extended Summary
}

Consumer experience, which refers to the interaction of the customer with the company and the brand as a consumer throughout his/her life, includes the perception of the customer and the brand image of the customer both at the level of consciousness and subconsciousness. The consumer experience can be realized either in physical environment or in virtual environment. As for the virtual environment, for example, consumers search for the goods or services they are in need of on the shopping site, compare the information which they find in association with the sought goods or services and then make the purchase decision online. This process provides the consumer with a comprehensive experience regarding the brand, product and service. Consumer experience is divided into sub-dimensions as behavioral, cognitive, emotional, sensory and relational. Each of these dimensions details the experience consumers have with the product or service.

Consumer experience is critical since it constitutes an effective component of the purchasing decision process. Purchasing decision process is considered by researchers as problem recognition, information seeking, evaluation of options, purchasing decision and post-purchase behavior (Nicosia, 1966; Howard \& Sheth, 1969; Engel, Blackwell \& Miniard, 1991). The experience of consumers regarding the product or service can shape this purchasing decision process. Such experience plays a fundamental role in determining the customers' preferences, which then influences their purchase decisions (Yang \& He, 2011, p. 6740).

Within this framework, the purchase intention, which is an important stage of the purchasing decision process, has a decisive effect on the action related to the purchase of the product. Bergeron (2004) defined purchasing intention as the level of perceptual opinion to purchase a product or service. Studies have shown that the online representation of the product and the overall quality of the shopping experience are important for both online shopping attitude and purchase intention (Koufaris, 2002). Consumers' willingness to buy a product or service via internet stores or virtual shopping carts is defined as online purchase intention (Close \& Kukar-Kinney, 2010). According to Chiu (2009) and Heijden et al. (2001), online purchase intention has dimensions of perceived service quality, perceived usefulness / utility, and perceived ease of use / purchase. Each dimension influences the online purchase intention.

Consumer experience and online purchase intention are shaped by technological advances. Augmented reality, a concept closely related to technology, reshapes advertising and marketing fundamentals and offers consumers a different experience. Augmented reality technology, which adds graphics, sound and other sensory enhancements to the real environment, is used in industrial design to visualize and take action, in the field of defense to detect threats in advance, in many game contents, in the field of marketing, which offers customers the opportunity to preview what is inside a product before unpacking it, spatial interactions, task support such as assembly and maintenance, and innovative products. For example, in pre-purchase situations, the consumer can predict how the living rooms will look with the new decoration with augmented reality applications (Flavián, Ibáñez-Sánchez \& 
Orús, 2019, p.548). In this context, augmented reality technology offers consumers a realistic evaluation opportunity for the products they want or need, regardless of location.

The aim of this study is to investigate the effects of marketing performed with augmented reality technology on the purchasing experience and online purchase intention of the consumer. In this article, since a study was conducted on how a phenomenon is perceived and experienced, phenomenology approach, one of the qualitative research designs, was used. The research is based on a qualitative study using face-to-face interviews, focus group interviews and observation techniques to collect data obtained through extensive interviews. In this study, since consumer experience and online purchase intention were measured, retired or working consumers who have economic purchasing power and used online shopping were preferred. Within the scope of the research, one-onone interviews with 6 consumers and 2 officials from a company and a focus group meeting with 4 consumers were held in Ankara. At the same time, in order to evaluate the application in more detail, a forum containing user opinions was examined. The obtained findings were analyzed with the QDA Miner program. In the light of the research, it is concluded that marketing with augmented reality has an effect on the consumer experience and online purchase intention. Although the results obtained from the interviews show that the participants have experienced the application for the first time, the fact that the participants clearly express positive and improvable aspects of the application show that augmented reality technology has an important potential in terms of marketing. Keywords: qualitative research, augmented reality, consumer experience, purchase intention 


\section{Giriş}

Tüketiciler, gelişen teknolojik uygulamalar sayesinde mağazadan veya internetten bir ürün veya hizmeti satın almaları durumundan daha farklı bir deneyim ve satın alma karar süreci yaşayabilmektedir. Günümüzün sürükleyici dijital teknolojilerinin, tüketicinin ihtiyaç duyduğu yerde ve zamanda gerçek zamanlı, bağlama özgü uzmanlık sunarak tüketici deneyimini dönüştürme potansiyeline sahip olduğu görülmektedir (Parise, Guinan \& Kafka, 2016). Özellikle, pazarlama temellerini yeniden şekillendiren, gerçek ve bilgisayarla yaratılmış verilerin bir karışımı olan artırılmış gerçeklik teknolojisi, tüketiciye eğlenceli, katılımcı ve sürükleyici bir deneyim (He, Wu \& Li, 2018; Stoyanova, Brito, Georgieva \& Milanova, 2015) olanağı tanıdığından reklamcılar tarafından ürünleri tanıtmanın yeni bir yolu olarak kabul edilmektedir (Stoyanova vd., 2015).

Artırılmış gerçeklik teknolojisi ile birleştirilmiş bir pazarlama ortamında tüketiciler duyusal, duygusal, düşünsel, davranışsal ve ilişkisel bağlamda tüketici deneyiminin tüm boyutlarını yaşayabilmektedir. Örneğin, satın alma öncesi durumlarda, tüketici, artırılmış gerçeklik uygulamalarıyla oturma odalarının yeni dekorasyonla nasıl görüneceğini öngörebilmektedir (Flavián, Ibáñez-Sánchez \& Orús, 2019). IKEA firmasının artırılmış gerçeklik içerikli mobil uygulaması ile tüketiciler, satın almadan önce ürünlerin evlerinde ne kadar yer kaplayacağına kadar görme imkânına sahip olabilmektedir. Bu deneyimler, tüketicilerin tercihlerini belirlemede temel bir rol oynamakta ve bu da daha sonra satın alma kararlarını etkilemektedir (Yang \& He, 2011).

Satın alma davranışının öncüsü olan karar alma süreci, genel çerçevede problem tanıma, bilgi arama, seçeneklerin değerlendirilmesi, satın alma kararı ve satın alma sonrası davranış olarak ele alınmaktadır (Engel, Blackwell \& Miniard, 1991; Howard \& Sheth, 1969; Nicosia, 1966). Satın alma karar sürecinin önemli bir aşaması olan satın alma niyeti, ürünün satın alınmasına ilişkin eylem üzerinde belirleyici bir etkiye sahiptir. Bergeron (2004) satın alma niyetini, ürün veya hizmeti satın almaya yönelik algısal kanaat düzeyi olarak tanımlamıştır. Satın alma niyeti ayrıca, tüketicinin uyaranlara karşı belirleyici tepkisini ortaya çıkaran en kritik satın alma karar süreci aşamalarından biridir (Tek, 1999).

Bununla beraber satın alma niyeti, bireylerin satın alınacak şeye ilişkin etüdüne ve o ürüne yönelik ilgisine göre bir tüketiciden diğerine değişkenlik göstermektedir. İnternet üzerinden de alışveriş imkânının ortaya çıkması ile tüketicilerin bir ürün veya hizmete yönelik satın alma niyeti aynı zamanda çevrimiçi ortamda da görülmeye başlanmıştır. İnternetten alışverişin; tüketiciler açısından zamandan ve emekten tasarruf sağladığı, sipariş vermeyi kolaylaştırdığı, malları iyi bir değer ve kalitede temin etme olanağı sağladığı, iyi bir site tasarımı ile finansal güvenlik sunduğu ve zengin bilgi erişimi sağladığı düşünüldüğünde tüketicilerin satın alma olasılığını etkileme potansiyeline sahip olduğu belirtilmektedir (Kim \& Kim, 2004). İnternet etkileşimi, anahtar sözcüklerle arama, çevrimiçi sipariş verme ve yorumlar yoluyla tüketicilerin deneyimlerini kişiselleştirmelerine ve özelleştirmelerine olanak sunmakta olup bu deneyim, web sitelerinin kalite derecelendirmesi üzerinde önemli bir olumlu etki yaratmaktadır (Ghose \& Dou, 1998). Bununla 
birlikte, Li, Daugherty ve Biocca (2002) araştırmaları sonucunda, internet aracılığıyla ürünleri üç boyutlu olarak inceleme olanağı sunan 3-D reklamların; tüketicilerin ürün bilgisini, marka tutumunu ve satın alma niyetini etkilediğini doğrulamıştır. Benzer şekilde Khan ve Sriram (2019) çalışmalarında artırılmış gerçeklik teknolojisinin de tüketicilerin satın alma niyetleri üzerinde etkisinin olduğu sonucuna varmıştır.

$\mathrm{Bu}$ çerçevede, artırılmış gerçeklik teknolojisi ile gerçekleştirilen pazarlamanın tüketici deneyimini ve çevrimiçi satın alma niyetini etkileyeceği düşünülmektedir. Stoyanova vd., (2015), Poushneh ve VasquezParraga (2017), Avcılar, Demirgüneş ve Açar (2019) nicel yöntemle yaptıkları araştırmalarda; artırılmış gerçeklik uygulamasının sağladığı kullanıma yönelik olumlu deneyimin satın alma niyetini doğrudan etkilediğini ortaya koymuşlardır. Bilici ve Özdemir (2019), yine nicel yöntemle; algılanan kullanım kolaylığı, algılanan eğlence, algılanan fayda ve algılanan bilgi vericilik boyutlarının kullanıcıların artırılmış gerçeklik teknolojisi kullanımına yönelik tutumlarını, bu tutumların ise söz konusu teknolojiyi kullanma niyetini etkilediği sonucuna varmışlardır. Artırılmış gerçeklik uygulamalarının tüketicinin satın alma niyetine olan olumlu etkilerini (Khan \& Sriram, 2019; Watson, Alexander \& Salavati, 2018) ve bahse konu uygulamaların tüketici deneyimine olan olumlu etkilerini (Köse \& Yengin, 2018) ele alan nicel çalışmalara da rastlanmıştır.

Artırılmış gerçeklik teknolojisi ile satın alma niyeti, kullanma niyeti veya tüketici deneyimi arasındaki neden-sonuç ilişkilerini nicel araştırma yöntemleri ile inceleyen anılan çalışmaların yanı sıra, Küçüksaraç ve Sayımer'in (2016) çalışmalarında artırılmış gerçeklik uygulamalarının tüketici deneyimine olan olumlu etkilerinin nitel yöntemle ortaya konulduğu görülmüştür.

Bu bağlamda, özellikle ulusal alan yazındaki çalışmalar incelendiğinde, artırılmış gerçeklikle pazarlama üzerine sınırlı sayıda nitel araştırmanın bulunması, ayrıca söz konusu sınırlı sayıdaki araştırmanın ise artırılmış gerçeklik uygulamasının hem tüketici deneyimi hem de çevrimiçi satın alma niyeti ile ilişkilerini beraber ele alan kapsamda olmaması sebebiyle, araştırmanın artırılmış gerçeklikle pazarlamanın tüketici deneyimi ve çevrimiçi satın alma niyeti ile ilişkilerinin nedenlerini alt boyutlanı ile ortaya koyan nitel bir çalışma olarak yazına katkı sağlayacağı değerlendirilmektedir.

Artırılmış gerçeklik uygulamasına yönelik tüketicilerin deneyim ve çevrimiçi satın alma niyeti araştırıldığından araştııılan konuyu, ilgili kişilerin bakış açılarından görebilmek ve bu bakış açılarını oluşturan sosyal yapıyı ve süreçleri ortaya koyabilmek (Yıldırım, 1999) maksadıyla insan deneyimlerinin ve eylemlerinin anlamına odaklanan (Sığnı, 2018) nitel araştırma yöntemi ile verilere ulaşılması hedeflenmiştir.

Aynı zamanda, araştırma bulgularının pazarlama uygulayıcıları için faydalı olacağı öngörülmektedir. Konunun tüketici deneyimi ve çevrimiçi satın alma niyeti çerçevesinde, ilgili kuram ve yaklaşımlarla ele alınmasının araştırmayı özgün kılacağı düşünülmektedir. 


\section{Artırılmış Gerçeklik Teknolojisi ve Pazarlama}

Artırılmış gerçeklik, gerçek zamanlı gerçek dünya görüntülerini (örneğin, kullanıcının yüzünü) bilgisayar tarafindan oluşturulan görüntülerle (örneğin sanal güneş gözlükleri) birleştirmektedir (Azuma, 1997). Bir başka ifadeyle, artırılmış gerçeklik gerçek dünyayı sanal nesneler ile tamamlamaktadır (Van Krevelen \& Poelman, 2010). Böylece artırılmış gerçeklik teknolojisi fiziksel dünyayı teknoloji ile birleştirerek algıyı geliştirmekte ve çevremizi zenginleştirilmiş bir şekilde görmemize, duymamıza ve hissetmemize yardımcı olmaktadır.

Artırılmış gerçeklik prototipleri Amerikalı bilgisayar bilimcisi Ivan Sutherland ve Harvard ile Utah Üniversitelerindeki öğrencileri tarafından 1960'larda başa takılı bir ekran aracıllı̆ıyla üç boyutlu grafiklerde kullanılmıştır. Artırılmış gerçeklik terim olarak ise ilk kez 1992 yılında Claudell ve Mizell (1992) tarafından “elle üretim süreçlerinde uyarı ekranı teknolojisi” kapsamında kullanılmıştır (Van Krevelen \& Poelman, 2010). 1990'lı yılların sonlarında, artırılmış gerçeklik konulu Uluslararası Artırılmış Gerçeklik Çalıştayı ve Sempozyumu, Uluslararası Karma Gerçeklik Sempozyumu ve Artırılmış Gerçeklik Ortamları Tasarımı atölye çalışması da dahil olmak üzere birçok konferans düzenlenmiştir (Azuma vd., 2001, s. 34). 2000'li yıllara gelindiğinde ise artırılmış gerçeklik uygulamalarının hayatı kolaylaştırıyor olması sebebi ile askeri alanda ve eğitim, bakım, tasarım, keşif, turizm ve pazarlama gibi birçok alanda kullanıldığı görülmektedir. Örneğin, Hyundai tarafından geliştirilmiş olan artırılmış gerçeklik fonksiyonu sayesinde telefona aracın motor bölümü gösterildiğinde arabanın yağına nasıl bakılacağından silecek suyunun nasıl doldurulacağına kadar ihtiyaca yönelik birçok konuda kullanıcıya özgü üç boyutlu görsel direktifler sunulmaktadır. 2016 yılında yayınlanan Pokemon Go mobil oyunu ise oyunun içerisinde yer alan çeşitli nesneleri gerçek hayattaki mekanlarla bir araya getirerek kullanıcılara farklı bir deneyim sunmuştur (Rauschnabel, Rossmann \& Tom Dieck, 2017). Freitas \& Campos (2008), ikinci sınıf öğrencileri için artırılmış gerçeklik sistemini geliştirmiştir. Bu sistem üç boyutlu modelleri ve prototipleri bir araya getirmiş, oyun temelli bir öğrenme sağlamıştır (Lee, 2012). Türkiye'de bir optik firması ise sanal deneme uygulaması ile mağazaya gitmeye gerek kalmadan bir gözlüğün kişide nasıl göründüğüne ilişkin olarak sanal ortamda gerçekçi bir deneyim sunmaktadır. Yine alışveriş marketlerinde Heinz Ketçap paketini telefonuna göstererek Blippar uygulaması sayesinde artırılmış gerçeklik teknolojisini kullanan bir tüketici ürün içeriğine, tariflerine ve çeşitli interaktif uygulamalarına erişim sağlayabilmektedir. Bu kapsamda artırılmış gerçeklik teknolojisinin, tüketicilere alışıldık deneyimlerinin dışında bir deneyim sağladığı görülmektedir.

Ürün içeriklerinin detaylarını öğrenmek, mağazadaki bir masa, koltuk veya sandalyenin evde nasıl gözükeceğini hayal edebilmenin ötesine geçebilmek, kıyafet veya aksesuarın denenmeden nasıl gözükeceği hakkında gerçekçi bir fikir edinmek, reklam içeriklerinin çekiciliğini artırmak açısından artırılmış gerçeklik teknolojisi pazarlama alanında giderek daha yoğun olarak kullanılmakta ve tüketicilere istek veya ihtiyaç duydukları ürünlere yönelik gerçekçi bir değerlendirme olanağını mekandan bağımsız olarak sunmaktadır. 
Firmalar artırılmış gerçeklik pazarlamasını, tüketiciler ve çalışanlar gibi toplumsal paydaşlarını hedeflemek amacıyla kullanmaktadır (Rauschnabel, Felix \& Hinsch, 2019). Bu teknoloji ile pazarlamacılar, fiziksel dünyadaki nesneler ve alanlar üzerine dijital bilgileri katmanlaştırmakta, böylece tüketiciler bu hibrit-karma gerçeklikleri dijital ekranlar veya projeksiyonlar aracılı̆̆ıyla deneyimlemektedir (Scholz \& Smith, 2016).

Geleneksel web tabanlı ürün sunumlarının aksine, artırılmış gerçeklik tabanlı sanal deneme, etkili ve ideal bir fantezi yaratıcısıdır; kullanıcıların anında kendi görüntülerini izlemelerine olanak sağlayarak mağazada alışveriş esnasında gizlilik sorununu gündeme getirebilecek başkalarına maruz kalma durumlarını önleyebilir ve mağazaya giderek satın alma davranışından daha iyi sonuç verebilir (Ferrer-Garcia \& Gutiérrez-Maldonado, 2012).

Mağaza ortamının kalabalık olması, ürünlerin dağınık bir şekilde bırakılması, deneme kabinlerinin doluluk oranı, mağaza görevlilerinin müşteriye davranışı, mağazaya erişim olanağı, zaman kısıtı gibi faktörler tüketicilerin satın alma niyetini şekillendiren unsurlar olarak bilinmektedir. Tüketici bu unsurları olumsuz olarak değerlendirdiğinde, satın alma davranışının gerçekleşmesinin de engellenebileceği öngörülmektedir. $\mathrm{Bu}$ olumsuz unsurları ortadan kaldıran artırılmış gerçeklik uygulamaları, ürünlerin pazarlanması açısından firmalara önemli katkılar sunmakla birlikte "tüketiciye fiziksel mağaza ortamından daha çok konfor sağlaması, internet tabanlı sanal mağaza ortamından daha çok gerçeklik ve kişiselleştirilmiş bir alışveriş deneyimi sunması" (Dacko, 2017) açısından tüketicinin çevrimiçi satın alma niyetini ve deneyimini olumlu yönde etkileyeceği düşünülmektedir.

\section{Tüketici Deneyimi}

Firmalar arası rekabetin fazla olduğu günümüzde, tüketici davranışının sadece rasyonel tarafına değil, bundan daha fazla irrasyonel ve duygusal tarafına da atıfta bulunan bir şirket ile müşterileri arasındaki etkileşimler kümesinden gelen tüm tecrübeyi hesaba katan tüketici deneyimini dikkate almak gerekli hale gelmiştir (Gentile, Spiller \& Noci, 2007). Firmalar açısından olumlu bir deneyim sunmak müşteri sadakatini artırırken tüketici açısından da memnuniyet derecesini artırmaktadır. Ek olarak, üst düzey işletme yöneticilerinin \%85'i yalnızca fiyat, ürün ve kalite gibi geleneksel unsurları farklılaştırmanın artık sürdürülebilir bir rekabet avantajı sağlamadığına ve dahası tüketici deneyiminin gelecekte rekabet avantajı sağlayan önemli bir alan olduğuna inanmaktadır (Shaw \& Ivens, 2005).

Tüketici deneyimi kişiseldir ve tüketicinin farklı seviyelerde (rasyonel, duygusal, duyulara ait fiziksel ve ruhsal) katılımını ifade eder (LaSalle \& Britton, 2003; Schmitt, 1999a). Schmitt'e göre tüketici deneyimi duyusal, duygusal, bilişsel, davranışsal ve ilişkisel değerler sağlamaktadır (Schmitt, 1999a, 1999b). Verhoef vd. (2009) ise tüketici deneyimini bilişsel, duyuşsal, duygusal, sosyal ve fiziksel/davranışsal boyutları ile ele almıştır. Bunlarla birlikte Fornerino vd. (2006) tüketici deneyimi için beş ayrı boyut tanımlamaktadır: duyusal-algısal, duyuşsal, fiziksel-davranışsal (bileşenler), sosyal ve bilişsel (yönler). Bu bağlamda mevcut literatürden yola çıkarak, tüketici deneyiminin boyutları olarak kabul ettiğimiz bileşenler: davranışsal/eylemsel, bilişsel/düşünsel, duygusal, duyusal ve ilişkisel deneyimdir. 
Davranışsal veya eylemsel deneyim, tüketicilerin hayatlarını zenginleştirmeyi ve onlara farklı yaşam tarzları sunmayı amaçlamaktadır. Kişilerin yaşam biçimi ve davranışlarına ilişkin değişimler büyük ölçüde güdüsel, ruhsal ve duygusal olmakta ve rol modellerle (film yıldızları ve sporcular gibi) desteklenmektedir. Hayat tarzlarında ve davranışlardaki değişiklikler genellikle tüketici için motive edici ve ilham verici olmaktadır (Kazançoğlu \& Aytekin, 2014). Nike'ın "sadece yap!" (just do it!) mottosu Schmitt'in (1999a) stratejik deneyimsel modüllerinden biri olan davranışlar ve yaşam tarzları modülünün bir klasiği haline gelmiştir. Söz konusu mottonun bireyi harekete geçirmeyi hedefleyen motive edici sözcükleri içerdiği görülmektedir. Bu bağlamda davranışsal deneyim, bireyin ürün veya hizmeti fiziksel açıdan deneyimlediği durumları ele almaktadır. Bu bakımdan davranışsal deneyim bireylerin fiziksel deneyimlerini hedefleyerek hayatlarını zenginleştirmekte ve bireylere yaşam tarzlarını ve etkileşimlerini değiştirmenin alternatif yollarını göstermektedir (Hsu \& Tsou, 2011).

Bilişsel veya düşünsel deneyim, tüketici deneyimini düşünme veya bilinçli zihinsel süreçlerle ilişkilendirmekte tüketicilerin yaratıcılıklarını veya problem çözme yetisini kullanmalarını sağlamaktadır. Hatta firma, bu bağlamda tüketiciyi bir ürün veya bazı genel zihinsel varsayımlar üzerindeki fikirlerini (genç bir kadının imajına sahip ilk bebek olan Barbie'de olduğu gibi) yenilemeye yönlendirebilir (Gentile, Spiller \& Noci, 2007). Bu deneyim tüketicilerin ürün veya hizmetler hakkında fikir beyan etmelerine olanak tanımaktadır. Bu kapsamda Microsoft'un "Bugün Nereye Gitmek İstersiniz?" kampanyası bilişsel deneyime iyi bir örnek teşkil etmektedir (Schmitt, 1999a).

Duygusal deneyimde firmalar, tüketicilerin içsel duygularına ulaşarak, onlarla empati kurarak ve hangi uyarıcıların onlarda hangi duyguları yarattığını öğrenerek markalarına ilişkin keyif, zevk gibi duygular yaratmaya çalışmaktadır (Kazançoğlu \& Aytekin, 2014). Örneğin, Eyüp Sabri Tuncer kolonyasının nostalji serilerinin satın alınması, tüketicinin anılarıyla ilişki kurmasına yol açmakta ve onlara duygusal bir deneyim sunmaktadır. Duygusal deneyim, hoşlanma ve hoşlanmamanın çok ötesinde tüketim deneyimine ilişkin tüm duyguları kapsamaktadır (Richins, 1997).

Duyusal deneyimde tüketiciler, görme, duyma, dokunma, tatma ve koklama yoluyla duyusal anlamda değer elde ederler (Schmitt 1999a \& 1999b). Örneğin, reklam müzikleri, sesler, siyah ve beyaz renkler, mağazaların dışardan görünür olması için aydınlatmanın güçlü olması, tasarım, paketleme ve stil tüketiciye duyusal deneyim sunmaktadır (Hultén, 2011). Çevrimiçi bir mağazada ürünleri incelerken görme, ürüne yakınlaşma, sayfayı değiştirme özelliklerini kullanırken cihaza dokunma ve markaya ilişkin bir müzik fonda çalarken duyma hislerinin meydana gelmesi tüketicinin duyusal bir deneyim yaşamasını sağlamaktadır.

İlişkisel deneyim, tüketicinin diğer insanlarla ya da ideal kişiliğiyle olan ilişkisini içeren bir tüketici deneyimi bileşeni olarak tanımlanmaktadır. İlişkisel deneyim, -örneğin Disneyland eğlence parklarında olduğu gibi diğer insanlarla birlikte kullanımı/tüketimi teşvik eden ve bir topluluğun yaratılmasını sağlayan bir ürünün tüketilmesine dair i) ortak bir tutkunun özü olan bir ürün olabilir (Gentile, Spiller \& Noci, 2007). Örneğin, Hard Rock Cafe sadece bir restoran olmasından ziyade belirli bir tür müzik severleri bir araya 
getiren ve hayran sayfaları bulunan bir marka haline gelmiştir. Bu yolla tüketicilere ilişkisel bir deneyim yaşatmaktadır. Son olarak ilişkisel deneyimde ürün (özel tasarım kıyafetler), aynı zamanda bir sosyal kimliğin onaylanması, bir aidiyet veya bir sosyal gruba ayrılma hissi uyandırma aracı olabilir (Gentile, Spiller \& Noci, 2007).

Artırılmış gerçekliğin tüketicilerin çevrimiçi ürün veya hizmetleri sanal olarak denemesine izin verme yeteneği, bilişsel ve görsel olarak çekici bir deneyim sağlar; tüketicileri, örneğin bir güneş gözlüğü takıldığında nasıl görüneceğini hayal etmenin zihinsel yükünden kurtarır (Hilken, Ruyter, Chylinski, Mahr \& Keeling, 2017). Bununla birlikte, artırılmış gerçeklik teknolojisi ile sunulan fiziksel kontrol biçimi, geleneksel web tabanlı kullanıcı kontrolünden farklıdır (Javornik 2016); ürünleri fiziksel olarak mevcut olmasa bile sanal ortamda fiziksel olarak değerlendirmesine ve onunla etkileşime girmesine olanak tanır (Hilken vd., 2017). Bu bağlamda, artırılmış gerçeklik sayesinde tüketicinin deneyimin tüm boyutlarını aynı anda yaşayabileceği öngörülmektedir.

\section{Çevrimiçi Satın Alma Niyeti}

Niyet, bir eylemi gerçekleştirme arzusunu temsil eden zihinsel bir süreç olarak tanımlanmaktadır (Bratman, 1987). Mutlu vd. (2011), niyetin bir şeyi yapmayı önceden isteyerek zihinde tasarlama anlamına geldiğini belirtmiş ve herhangi bir davranışı gerçekleştirmeye yönelik fiili iradenin önemli bir göstergesi olduğunu ifade etmişlerdir. Satın alma sürecinde satın alma davranışının gerçekleşmesi açısından da son derece önemli olan niyeti, Rezvani vd. (2012), kişinin bir davranışı sergilemesi açısından motivasyonu olarak tanımlamışlardır.

Araştırmalar, ürünün çevrimiçi olarak temsil edilmesinin ve alışveriş deneyiminin genel kalitesinin hem çevrimiçi alışverişe yönelik tutum hem de satın alma niyeti için önemli olduğunu göstermiştir (Koufaris, 2002). Chiu (2009) ile Heijden vd. (2001) göre çevrimiçi satın alma niyetinin; algılanan hizmetin kalitesi, algılanan kullanışlılık/fayda ve algılanan kullanım/satın alma kolaylığı boyutları bulunmaktadır.

Algılanan hizmetin kalitesinde istikrarlı hizmet kalitesi algısı, müşteri memnuniyetini ve güvenini artırmaktadır (Ling \& Ding, 2006). Zeithaml vd. (1996), kaliteli bir hizmet alan çevrimiçi müşterilerin olumlu davranışsal niyet sergilemelerinin muhtemel olduğunu belirtmiştir. Bu da çevrimiçi satın alma niyetinin artmasına neden olmaktadır. Bu bağlamda algılanan hizmet kalitesinin yüksek olmasının tüketicilerin çevrimiçi satın alma niyetlerini olumlu yönde etkileyeceği öngörülmektedir.

Algılanan kullanışlılık/fayda, internet kullanım etkinlikleri olan mesajlaşma, tarama, indirme ve satın alma ile ilişkilendirilmektedir (Teo, 2001). Chiu (2009) çalışmasında e-turizm perspektifinden bakıldığında, çevrimiçi satın alımlar için algılanan faydayı, potansiyel tüketicinin interneti kullanarak ürününü satın almasını verimli bir şekilde kolaylaştırma olasılığı olarak tanımlamaktadır.

Çevrimiçi satın alma için algılanan kullanım kolaylığı, potansiyel müşterinin çevrimiçi satın alımlarında beklediği çaba göstermeme derecesini ifade etmektedir (Koufaris, 2002). Web sitesinin algılanan kullanım kolaylığının ise çevrimiçi satın alma konusundaki tutumu etkilediği gösterilmiştir (Heijden vd., 2001). 


\section{Nitel Araştırma Yöntemi ve Süreci}

Teknolojinin hayatın her alanında hâkim olduğu bir dünyada artırılmış gerçeklik teknolojisi küresel pazarda tüketicilerin kullanımına sunulmaya başlanmıştır. Söz konusu teknolojinin hızla pazarda yayılacağı göz önüne alındığında, tüketici deneyimi ve çevrimiçi satın alma niyeti üzerine etkilerinin ne olacağı sorusu önem arz etmektedir. Bu nedenle bu çalışmanın amacı, artırılmış gerçeklik ile gerçekleşen pazarlama faaliyetlerinin, tüketici deneyimi ve çevrimiçi satın alma niyeti ile ilişkilerini tespit ederek bu ilişkilerin nedenlerini ortaya koymaktır. Yapılan alan yazın taramasında artırılmış gerçekliği tüketici deneyimi ve satın alma niyeti olguları bütününde ele alan nitel bir çalışmaya rastlanılmadığından, çalışmanın akademik yazına katk1 sağlayacağı düşünülmektedir. Bu kapsamda "artırılmış gerçekliğin tüketici deneyimi üzerindeki etkisi nedir?", “artırllmış gerçeklik markaların pazarlanmasında geleneksel yöntemlerden hangi yönleri ile avantajlı görülmektedir?”, "artırılmış gerçeklik, markaların tüketicilere nasıl pazarlanabileceğine dair yeni olasılıklar ortaya koymakta mıdır?” ve “artırılmış gerçekliğin kullanılması tüketicilerde çevrimiçi satın alma niyetini etkiler mi?" sorularına yanıt aranmaktadır.

\section{Araştırma Deseni}

$\mathrm{Bu}$ araştırmada; olaylar, deneyimler, algılar, yönelimler, kavramlar ve durumlar gibi çeşitli biçimlerde karşımıza çıkan olgulara (Yıldırım \& Şimşek, 2011) odaklanan fenomenoloji deseni tercih edilmiştir. Tüketicilerin artırılmış gerçeklik teknolojisi deneyimine ilişkin görüşlerini ve satın alma niyetini değerlendirebilmek açısından bu desenin daha uygun olacağı düşünülmüştür.

\section{Çalışma Grubu ve Veri Toplama Teknikleri}

$\mathrm{Bu}$ çalışmada amaçlı örnekleme yöntemlerinden ölçüt örnekleme yoluyla örneklem oluşturulmuştur. "Amaçlı örneklem, sayıdan ziyade, amaçlanan konuya bizi en iyi götürebilecek olan denek grup ve kişilerinin seçimini esas almaktadır" (Sığrı, 2017). Ölçüt örneklemde, belirlenen temel nitelikleri karşılayan birimler örnekleme dâhil edilmektedir. Söz konusu ölçütler araştırmacı tarafından ya da önceden hazırlanmış bir ölçüt listesi aracılığıyla oluşturulabilir (Yıldırım \& Şimşek 2008). Bu araştırmada tüketici deneyimi ve çevrimiçi satın alma niyeti ölçüldüğünden düzenli geliri olan ve internet üzerinden alışveriş yapan emekli veya çalışmakta olan tüketiciler tercih edilmiştir. Gelire sahip olmak, satın alma niyetini etkileyen önemli faktörlerden biri olduğundan (Casper, 2007; Özden, 2017) ve araştırmada internet üzerinden alışverişe yönelik tüketicilere görüşler sorulduğundan bu ölçütler örneklem oluşturulurken kullanılmıştır. Bununla birlikte, artırılmış gerçeklik teknolojisini ürünlerinde kullanan bir teknoloji firmasının yetkililerinin görüşlerine de yer verilmiştir. Araştırma kapsamında 6 tüketici ve bir teknoloji firmasından 2 yetkiliyle birebir görüşme, 4 tüketici ile ise odak grup görüşmesi Kasım-Aralık 2019 tarihleri arasında Ankara ilinde gerçekleştirilmiştir. Bahse konu görüşmeler tüketicilerle ofis ve ev ortamlarında, firma yetkilileri ile teknoloji fuarında yer alan ofislerinde, odak grup katılımcıları ile ise sessiz bir ortamın sağlanması ön koşuluyla bir kafede yapılmıştır. Baş ve Akturan (2013), görüşme sürecine başlamadan önce araştırmacının; araştırma amacını ve kendisini katılımcıya açıkça ifade etmesinin önemine değinmekte, aktif ve sabırlı bir dinleyici olması ve esnek davranması gerektiğini vurgulamakta; görüşmeye öncelikle genel 
konulardan ve sorulardan başlayarak daha sonra detay ve özel konulara değinmesinde fayda olacağını ifade etmektedirler. Bu hususlara dikkat edilerek görüşmeler gerçekleştirilmiş, katılımcıların izinleri alınmış, araştırmanın amaç ve kapsamı hakkında bilgiler verilmiştir. Mülakat süresince katılımcıların verdikleri cevaplar not edilmiş ve katılımcıların izni dâhilinde ses kaydına alınmıştır. Görüşmeler yaklaşık 25-30 dakika sürmüştür.

Tablo 1. Katılımcıların Sosyo-demografik Dağılımı

\begin{tabular}{ccccc}
\hline Katılımcılar & Cinsiyet & Yaş & Meslek & Ĕ̈itim \\
\hline Katılımcı1 & Kadın & 50 & Muhasebeci & Lise Mezunu \\
Katılımcı2 & Erkek & 58 & İşletme Müdürü & Lise Mezunu \\
Katılımcı3 & Kadın & 38 & Satın Alma Uzmanı & Lisans \\
Katılımcı4 & Kadın & 31 & Satın Alma Uzman & Lisans \\
Katılımcı5 & Kadın & 31 & Satın Alma Uzmanı & Lisans \\
Katılımcı6 & Erkek & 25 & Mühendis & Lisans \\
Firma Yetkilisi1 & Erkek & 30 & Mühendis & Lisans \\
Firma Yetkilisi2 & Kadın & 43 & Pazarlama Uzmanı & Lisans \\
Odak Grup Katılımcı1 & Erkek & 27 & Mühendis & Yüksek Lisans \\
Odak Grup Katılımcı2 & Erkek & 26 & Bürokrat & Lisans \\
Odak Grup Katılımcı3 & Erkek & 29 & Bürokrat & Lisans \\
Odak Grup Katılımcı4 & Erkek & 33 & Diplomat & Yüksek Lisans \\
\hline
\end{tabular}

Tablo 1'de çalışmanın örneklemini oluşturan 7 erkek, 4 kadın katılımcının büyük çoğunluğunun lisans mezunu olduğu görülmektedir. 23-30 yaş aralığında 4 katılımc1, 30-40 yaş aralığında 4 katılımc1, 40-50 yaş aralığında 1 katılımcı ve 50-60 yaş aralığında ise 2 katılımcı bulunmaktadır.

Artırılmış gerçeklik uygulaması birçok mobil platformda yaygın hale gelmeye başlamıştır. Türkiye'de artırılmış gerçeklik üzerine çalışmalar gerçekleştiren en büyük firmalardan biri olan Blippar firması Renault, Knorr, Vivident, Pepsi, Heinz gibi ünlü markaların reklamlarında veya ürünlerinde artırılmış gerçekliği tüketiciler ile buluşturmaktadır. Bu kapsamda Blippar firmasının uygulamaları ile ilgili görüşler Google Play Store ve çeşitli forumlarda incelenerek doküman incelemesi yapılmıştır.

Tüketicilerin artırılmış gerçeklik uygulamasına yönelik deneyimini ve çevrimiçi satın alma niyetini öğrenmek amacıyla birebir görüşmeler yoluyla yarı deney ortamında deneyimledikleri uygulama hakkındaki görüşleri Kazançoğlu ve Aytekin (2014), Heijden vd. (2001) ve Ylinen (2012) tarafından gerçekleştirilmiş olan çalışmalardan uyarlanan ve EK-1'de verilen yarı yapılandırılmış mülakat soruları çerçevesinde alınmıştır. Bu maksatla, araştırma sorusunun cevabının alınması amacıyla, yarı deney tasarımı için uygun deney şartı sağlayan bazı ürünler bu çalışmada kullanılmıştır. Yarı deney uygulanmadan önce tüketicilere Heinz ve Knorr markaları hakkındaki görüşleri sorulmuş, ardından tüm katılımcıların mobil telefon üzerinden Google Play Store aracılığıyla yüklenmiş olan Blippar uygulamasını kullanarak Heinz marka ketçap ve Knorr marka çıtır pane harcı paketlerinde bulunan artırılmış gerçeklik içeriklerini deneyimlemeleri sağlanmıştır (Şekil 1). Katılımcılar, Blippar uygulaması ile telefon kamerasını açarak ürün paketlerine tuttuklarında ürün içeriğine yönelik üç boyutlu hologramlar belirmiş ve artırılmış gerçeklik teknolojisi içeriklerine maruz kalmışlardır. Heinz marka ketçap ambalajında yer alan içerik, tüketicilerin tarifleri görüntülemelerine ve incelemelerine olanak tanımıştır. Knorr marka çıtır pane ambalajında yer alan 
içerik ise tüketicilerin çıtır pane harcını nasıl kullanacaklarını etkileşimli bir şekilde deneyimlemelerini sağlamıştır. Artırılmış gerçeklik içeriklerinin sırası tüm mülakatlar için aynı tutulmuştur. Ardından tüketicilerin "Smart Buy Glasses" isimli gözlük satış sitesinde yer alan artırılmış gerçeklik teknolojisi ile yüzlerini ekrana tanıtarak diledikleri gözlükleri denemeleri istenmiştir (Şekil 1). Böylece tüketicilerin artırılmış gerçeklik uygulamasını farklı ürün içerikleriyle ve hem mobil hem de web sitesi yoluyla deneyimlemeleri sağlanmıştır. Yarı deney sırasında tüketicilerin görüşleri mülakat soruları yoluyla ve doğrudan gözlem yoluyla alınmıştır.

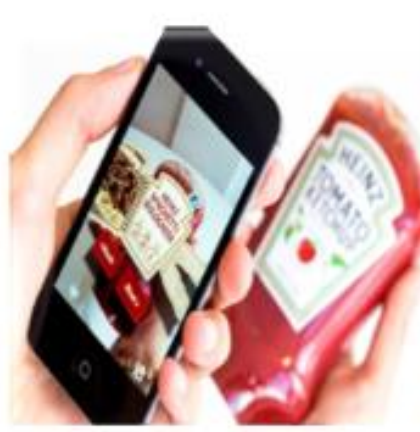

Heinz Ketçap Uygulama Görseli

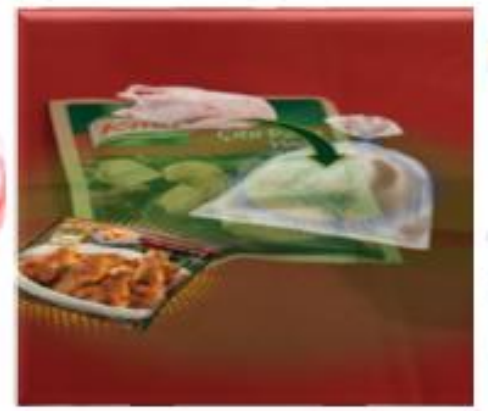

Knorr Çitır Pane Harc1 Uygulama Görseli

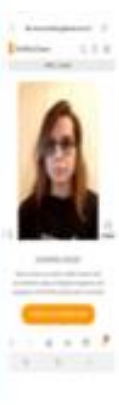

SmartBuyGlasses Uygulama
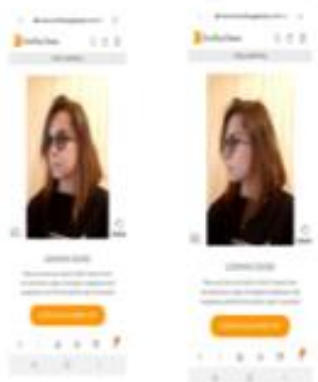

Görseli

Şekil 1. Yarı Deney Kapsamında Artırılmış Gerçeklik Uygulamasında Kullanılan Görseller

Artırılmış gerçeklik uygulamasını ürünlerine entegre etmiş olan mühendislik ve teknoloji firmasından yetkili kişilerle de, EK-2'de sunulan mülakat yapılarak firma nezdinde tüketici deneyimleri ve satın alma niyetleri değerlendirilmiştir. Son olarak, tüketicilerin sosyal çevrelerinden etkilendiği varsayımıyla satın alma niyetlerinde çevrelerinin etkisini görebilmek amacıyla mülakat dışında odak grup görüşmesi de yapılmıştır.

\section{Veri Analiz Tekniği}

Öncelikle görüşme kayıtları çözümleme yapılarak yazılı hale getirilmiştir. Elde edilen nitel veriler QDA Miner programı aracılığıyla içerik analizine tabi tutulmuştur. Katılımcıların verdiği yanıtlar ve ilgili alan yazın (Chiu 2007; Gentile, Spiller \& Noci, 2007; Schmitt, 1999b) dikkate alınarak kodlar belirlenmiştir. Kodlardan birbiriyle ilişkili olanlar gruplandırılmış ve literatürdeki kavramlarla karşılaştırılarak temalar oluşturulmuştur. Kodların frekansı, katılımcılar arası benzerlik, cinsiyete göre kodların frekansı ve kodlar arası yakınlık analiz edilmiş, elde edilen veriler doğrultusunda çıkarımda bulunulmuştur.

\section{Bulgular}

\section{Mülakat ve Odak Grup Görüşmeleri Analizi}

Tüketici deneyimi ve çevrimiçi satın alma niyetine ilişkin birebir yüz yüze mülakat ve odak grup görüşmelerinde tüketicilerin belirttikleri ifadeler literatürdeki kavramlar çerçevesindeki kodlarla ilişkilendirilmiştir. Bu kodlara ilişkin sıklıklar ise frekans analizi ile elde edilmiştir. 
Tüketici deneyimi ve çevrimiçi satın alma niyetine ilişkin katılımcıların ifade ettiği hususlar bağlamında kodların kullanım sıklığı Tablo 2'de gösterilmiştir.

Tablo 2. Tüketici Deneyimine ve Çevrimiçi Satın Alma Niyetine İlişkin Kodların Frekans Analizi

\begin{tabular}{|c|c|c|c|c|c|}
\hline & Temalar & Kodlar & Tanımları & Sıklık & $\%$ \\
\hline \multirow{29}{*}{ 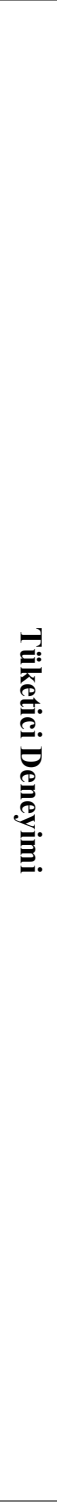 } & \multirow{5}{*}{$\begin{array}{l}\text { Davranışsal } \\
\text { Deneyim }\end{array}$} & Seçim yapmak & İçerikle ilgili tercihte bulunabilmeyi ifade eder. & 12 & 3,4 \\
\hline & & Güçlü k1lmak & Uygulama üzerindeki kontrol yetisini ifade eder. & 4 & 1,1 \\
\hline & & Kontrol & İçerik üzerinde hakimiyet kurmayı ifade eder. & 12 & 3,4 \\
\hline & & Etkileşim & İçerik ile birey arasındaki etkileşimi ifade eder. & 9 & 2,5 \\
\hline & & $\begin{array}{l}\text { Katılım } \\
\text { göstermek }\end{array}$ & Tüketicinin aktif katılım göstermesidir. & 10 & 2,8 \\
\hline & \multirow{7}{*}{$\begin{array}{l}\text { Bilişsel/Düşünsel } \\
\text { Deneyim }\end{array}$} & Odaklanmak & İçeriğe yoğunlaşmak anlamına gelir. & 10 & 2,8 \\
\hline & & Tanımak & $\begin{array}{l}\text { Tüketicilerin ürünleri tanıması ve önceki bilgileriyle } \\
\text { bağlantı kurması olarak tanımlanmıştır. }\end{array}$ & 11 & 3,1 \\
\hline & & Marka imajı & Tüketicilerin ürüne ilişkin görüşlerini ifade eder. & 15 & 4,2 \\
\hline & & Değerlendirmek & $\begin{array}{l}\text { İçeriğe ilişkin tüketicilerin fikir/görüşlerini ifade } \\
\text { eder. }\end{array}$ & 25 & 7,1 \\
\hline & & Hatırlamak & Ürünle ilgili akla gelen ifadelerdir. & 2 & 0,6 \\
\hline & & $\begin{array}{l}\text { Durumsal } \\
\text { Farkındalık }\end{array}$ & $\begin{array}{l}\text { Çevresindeki uyarıcılara ilişkin algıyı ifade } \\
\text { etmektedir. }\end{array}$ & 1 & 0,3 \\
\hline & & $\begin{array}{l}\text { Merak/Problem } \\
\text { çözme }\end{array}$ & $\begin{array}{l}\text { İçerikle ilgili merak duyma ve problem çözme } \\
\text { duygularını ifade etmektedir. }\end{array}$ & 10 & 2,8 \\
\hline & \multirow{9}{*}{$\begin{array}{l}\text { Duygusal } \\
\text { Deneyim }\end{array}$} & Eğlenme & İçerikle ilgili zevk almayı ifade eder. & 10 & 2,8 \\
\hline & & Şaşırma & İçerikle ilgili şaşırmayı ifade eder. & 15 & 4,2 \\
\hline & & Beğenme & Uygulamayi beğenip beğenmemeyi ifade eder. & 15 & 4,2 \\
\hline & & Heyecan & Uygulamaya karşı heyecan duymayı ifade eder. & 1 & 0,3 \\
\hline & & Zorlu & Uygulamanın zor olmasını ifade eder. & 5 & 1,4 \\
\hline & & Tereddüt etmek & İkilemde kalmayı ifade eder. & 1 & 0,3 \\
\hline & & Cezbetmek & Uygulamanın ilgi çekmesini ifade eder. & 6 & 1,7 \\
\hline & & Farkl1 & Uygulamanın değişik olduğunu ifade eder. & 2 & 0,6 \\
\hline & & Güven & Uygulamaya ilişkin güven duymayı ifade eder. & 9 & 2,5 \\
\hline & \multirow{5}{*}{ İlişkisel Deneyim } & Marka bağ 1 & Tüketicinin marka ile kurduğu bağı ifade eder. & 2 & 0,6 \\
\hline & & İlişkilendirmek & $\begin{array}{l}\text { Kendi benliği ile markayı ilişkilendirmek anlamına } \\
\text { gelir. }\end{array}$ & 7 & 2 \\
\hline & & Parçası olmak & Grubun bir parçası olmayı ifade eder. & 8 & 2,3 \\
\hline & & Sosyalleşmek & Arkadaş edinme anlamına gelir. & 2 & 0,6 \\
\hline & & Paylaşmak & Başkaları ile paylaşmayı ifade eder. & 7 & 2 \\
\hline & \multirow{3}{*}{ Duyusal Deneyim } & Duyma & İçerikteki sesin algılanmasını ifade eder. & 5 & 1,4 \\
\hline & & Dokunma & İçerikteki dokunma işlevini ifade eder. & 11 & 3,1 \\
\hline & & Görme & İçeriğin görünüşünü ifade eder. & 19 & 5,4 \\
\hline \multirow{9}{*}{ 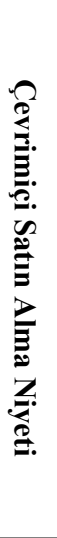 } & \multirow{3}{*}{$\begin{array}{c}\text { Algilanan } \\
\text { Hizmetin Kalitesi }\end{array}$} & Memnuniyet & Uygulamaya yönelik memnuniyeti ifade eder. & 14 & 4 \\
\hline & & Beklenti & $\begin{array}{l}\text { Tüketicilerin uygulama hakkındaki beklentileri ile } \\
\text { deneyimleri arasındaki ilişkiyi ifade eder. }\end{array}$ & 2 & 0,6 \\
\hline & & Kiyaslama & $\begin{array}{l}\text { Mağaza veya doğrudan web sitesinden satın almaya } \\
\text { kıyasla bu yönteme ilişkin düşünceleri ifade eder. }\end{array}$ & 23 & 6,5 \\
\hline & \multirow{3}{*}{$\begin{array}{c}\text { Algılanan } \\
\text { Kullanışlilık/Fayda }\end{array}$} & Hizlı & $\begin{array}{l}\text { Uygulamanın kullanılmasının hızlı olmasını ifade } \\
\text { eder. }\end{array}$ & 5 & 1,4 \\
\hline & & Kullanici dostu & Uygulamanın kullanıcı dostu olmasını ifade eder. & 13 & 3,7 \\
\hline & & Anlaşılabilir & Uygulamanın anlaşılabilir olduğunu ifade eder. & 6 & 1,7 \\
\hline & \multirow{3}{*}{$\begin{array}{c}\text { Algılanan } \\
\text { Kullanım/Satın } \\
\text { Alma Kolaylığ } 1\end{array}$} & Zahmetsiz & Uygulamayı çaba harcamadan kullanmayı ifade eder. & 12 & 3,4 \\
\hline & & Zaman azaltır & $\begin{array}{l}\text { Uygulamanın kişinin satın alma durumunda } \\
\text { harcadığı zamanı azaltmasını ifade eder. }\end{array}$ & 9 & 2,5 \\
\hline & & Faydalı görmek & $\begin{array}{l}\text { Uygulamanın satın alma açısından yararlı olduğunu } \\
\text { ifade eder. }\end{array}$ & 23 & 6,5 \\
\hline
\end{tabular}


Katılımcıların büyük çoğunluğu, bilişsel/düşünsel deneyim temasının, içeriğe ilişkin tüketicilerin fikir/görüşlerini yansıtan değerlendirme koduna ilişkin ifadelerde bulunmuşlardır. Örneğin Katılımcı 5 (Kadın, 31) artırılmış gerçeklik uygulamasını aşağıdaki şekilde değerlendirmektedir:

“Şu gözlük uygulamasında tam 360 derece bir şey yok gibi sanki kısitll gibi. İlk gözlüğ̈̈mü alırken tamamın aldı ama internetin yavaşlığından dolayıdır belki şu anda hani günlük bir şey de yaşlyor olabiliriz. Yukarıdan, aşağıdan, sağdan, soldan baktı̆̆ım bir şey olsa, daha geniş bir perspektif olsa daha iyi olur gibi düşündüm. Ama genel hatlarıyla güzel bir program çıkarmışlar. Tekstil gibi diğer alanlara da uyarlanabilmesi gerekir". Odak grup görüşmesinde Odak Grup Katılımcı 3 (Erkek, 29) ise uygulamayı aşağıdaki gibi değerlendirmiştir:

"Kafayı sağa sola çevirmenin yetmesi gerekiyor mesela. Kamerayı açtın ya kafanı sağa sola çevir ve direkt denemeye başla. Biraz hız kazanması gerekiyor. İkincisi diğer aşamaları (o butona bas, şuraya bas, buraya bas) geçmesi gerekiyor. Son olarak da Heinz Ketçap ve Knorr Tavuk Harcı üzerindeki deneyimden şunu çlkarlyorum. Gözlüğ̈̈ biz neden beğendik, çünkü gözlükte sürece bizi dahil etti. Bizim resmimiz var orada, üstüne gözlüğ̈̈ taktı falan. Ama bunda (diğer deney konusu ürünler) süreçte biz yokuz. Ürüne tutuyoruz ürünün üzerinden geçiyor. Yani olaya bizim de girmemiz söz konusu olursa daha çok benimsiyoruz tüketici olarak",

Katılımcıların genel olarak, uygulamaya ilişkin geliştirilmesi gereken yönlerin bulunduğunu vurguladıkları tespit edilmiştir.

Dağılımda görme kodunun da sıklıkla geçtiği tespit edilmiştir. Duyusal deneyimin bir kodu olan görme; uygulamanın ve ürünün rengi, stili, görüntü kalitesi ve resimlerine ilişkin görünüşle ilgili ifadeleri kapsamaktadır. Bu bağlamda katılımcılar aşağıdaki görüşlerde bulunmuşlardır:

“Görüntü kalitesi güzel.”(Katılımcı 1, Kadın, 50)

"Yakını görebiliyoruz. Nasıl yakıştığını görebiliyoruz”. (Katılımcı 6, Erkek, 25)

"Mesela asker gözlüğ̈̈ takiyor, etrafindaki semboller yardımıyla dost birlikler düşman birlikleri vs. onları görebiliyor". (Firma Yetkilisi 1, Erkek, 30)

Araştırma kapsamında görüntü kalitesine ilişkin genel olarak olumlu ifadelere yer verildiği görülmüştür.

Duygusal deneyime ilişkin şaşırma ve beğenme ile bilişsel/düşünsel deneyime ilişkin marka imajı kodları aynı oranda dă̆glım göstermiştir.

Çevrimiçi satın alma niyeti boyutları olan algılanan hizmetin kalitesine, algılanan kullanışlılık/faydaya ve algılanan kullanım kolaylığına ilişkin katılımcıların ifade ettiği hususlar bağlamında en çok dağılımı alan kod kıyaslama ve faydalı görmek iken; memnuniyet, kullanıcı dostu, zahmetsiz, zaman azaltır, anlaşılabilir, hılı ve beklenti kodları sirasıyla gelmektedir.

Tüketicilerin artırılmış gerçeklik uygulamasını kullanmadan doğrudan mağaza veya internet yoluyla satın alma niyetlerine ilişkin sorulara verdikleri yanıtlar, katılımcıların büyük çoğunluğunun algılanan hizmetin kalitesinin bir kodu olan kıyaslama ifadelerinde bulunduklarını göstermektedir. Ayrıca algılanan kullanım/satın alma kolaylığının bir kodu olan ve uygulamanın yarar sağladığı anlamına gelen faydalı görmek kodu da aynı sıklıkta kullanılmıştır. Katılımcı 4 (Kadın, 31) ise faydalı görmek bağlamında " $B u$ yönüyle bence online alışverişi artıracak” yorumunda bulunmuştur. Yine Katılımc1 2 (Erkek, 58) kıyaslama kapsamında aşağıdaki ifadeleri kullanmıştır.

"Uygulamayı gördükten sonra uygulamanın daha mantıklı olduğunu düşünüyorum. Tabii ikinci olarak da gidip bir mağazadan almak daha manttkl geliyor bana. Web sitelerinde tam istediğimiz ürünün bize gelip gelmeyeceği, ürünün içeriğinin baktı̆̆ımız ürünle aynı olup olmadığını anlayamayız. Ama bu şekilde içeriğini bilerek ve istediğimiz bir ürün olduğunu tam anlamıyla bildikten sonra uygulama güzel. İnternette de olursa bu tür bir uygulama tercih edilebilir". 
Tüketicilere "bir ürün satın almaya niyetlendiğinizde artırılmış gerçeklik uygulaması ile mi satın almayı, artırılmış gerçeklik uygulaması kullanmadan web sitesi yoluyla mı satın almayı yoksa mağazaya giderek mi satın almayı düşünürsünüz?” sorusu yöneltilmiştir. Katılımcıların verdikleri yanıtlar ise aşağıda yer almaktadır.

"Böyle satın almayı tercih ederim ama mağazayı daha çok tercih ederim”. (Katılımcı 1, Kadın, 50)

"Üründen ürüne de değişir aslında. Ama online alışveriş̧ bence insanın hayatını çok kolaylaşttran bir şey. Artırlmıı̧ gerçeklikte bir ürünün sana olup olmayacağını deneme imkânı tanıyorsa, kesinlikle o yola başvurmak isterim. Yani doğru uygulandığında ve bu imkânı tanıdı̆̆ında măgazanın önüne geçer, bayă̆l kitler yani ekranın karşısına. Çünkü çok kolay yani tercih ederdim iyi uygulandı̆̆ında". (Katılımcı 3, Kadın, 38)

"Mağaza, artırllmış gerçeklik, web sitesinden alı̧veriş yapmak olarak sıralama yapabilirim". (Katılımcı 4, Kadın, 31)

"Normalde ben çok mağazacı bir tipim ama artırlmış gerçeklikle bir kez olumlu deneyim yaşayıp güven duygum gelişirse bundan sonra artırlmış gerçeklikle internet üzerinden alışveriş yapmayı tercih edebilirim". (Katılımc1 5, Kadın, 31)

"Şöyle birincisi mağazadan ikincisi artırllmış gerçeklikle mağazadan üçüncüsü internetten". (Katılımcı 6, Erkek, 25)

Odak grubun görüşleri ise aşağıdaki gibi olmuştur:

“Aslında ürüne çok bağll.” (Odak Grup Katılımc1 1, Erkek, 27; Odak Grup Katılımcı 2, Erkek, 26; Odak Grup Katılımc1 3, Erkek, 29)

"Ürün gözlükse tabii ki artırlmış gerçeklik uygulamasıyla denemek daha güzel. Ama ürünün ne olduğuna bağlı yani. Küvet alacaksam eve, herhalde artırlmış gerçeklikle içinde nasıl duruyorum diye merak etmem”. (Odak Grup Katılımc1 3, Erkek, 29)

Kümeleme analizi diyagramlarından biri olan ve belirli kavramların birbirleriyle yakınlıklarının saptanması amacıyla (Sığrı, 2018) kullanılan dendrogram grafiği (Şekil 2) incelenmiştir. Grafikteki çizgilerin yüksekliği, genel olarak kodların birbirlerine ne kadar benzer veya farklı olduklarını göstermektedir: yükseklik ne kadar büyükse, fark o kadar büyük olur. Kodlar arası yakınlık ilişkisi incelendiğinde, paylaşmak ve tanımak kodlarının birbiri ile en yakın ilişki içinde olduğu, daha sonra ise odaklanmak ile paylaşmak ve tanımak kodlarının birbirleri ile yakın ilişki içinde olduğu görülmektedir. Kontrol ve şaşırma kodlarının da benzer şekilde yakın ilişkiye sahip olduğu görülmektedir. Bu bağlamda tüketici deneyimi boyutlarından bilişsel/düşünsel deneyim ile ilişkisel deneyim ve davranışsal deneyim ile duygusal deneyim arasında yakın ilişki olduğu görülmektedir. Söz konusu yakın ilişki göz önünde bulundurulduğunda tüketici deneyimini bir bütün olarak değerlendirebilmek açısından alt boyutların bir arada ele alınmasının önemli olduğu görülmektedir. 


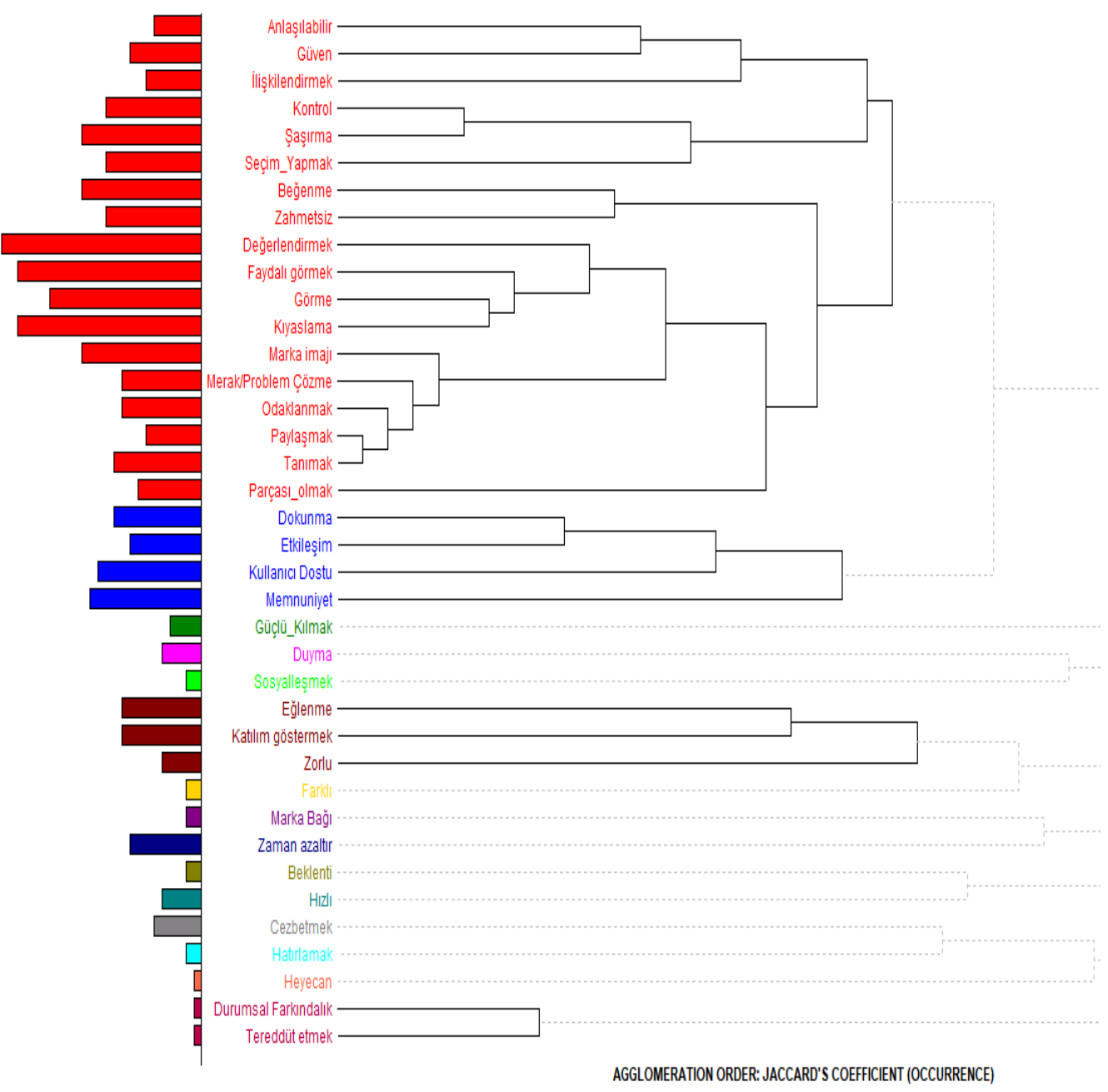

Şekil 2. Kodlar Arası İlişki- Dendrogram Grafiği

Kodlar ve katılımcılar arasındaki ilişkiye (Şekil 3) bakıldığında ise odak grubun ve firmanın diğer katılımcılardan daha farklı ifadelerde bulunduğu görülmektedir. Odak grup mülakatında, birebir mülakata kıyasla katılımcılar arasında etkileşimin bulunduğu ve cevapların buna göre şekillendiği kanaati güçlenmektedir. Firma mülakatında ise yetkililer, tüketicilerden farklı olarak söz konusu teknolojiyi birebir ürünlerinde kullandıkları için özellikle artıılmış gerçekliğin durumsal farkındalık sağladığına değinmişlerdir. 


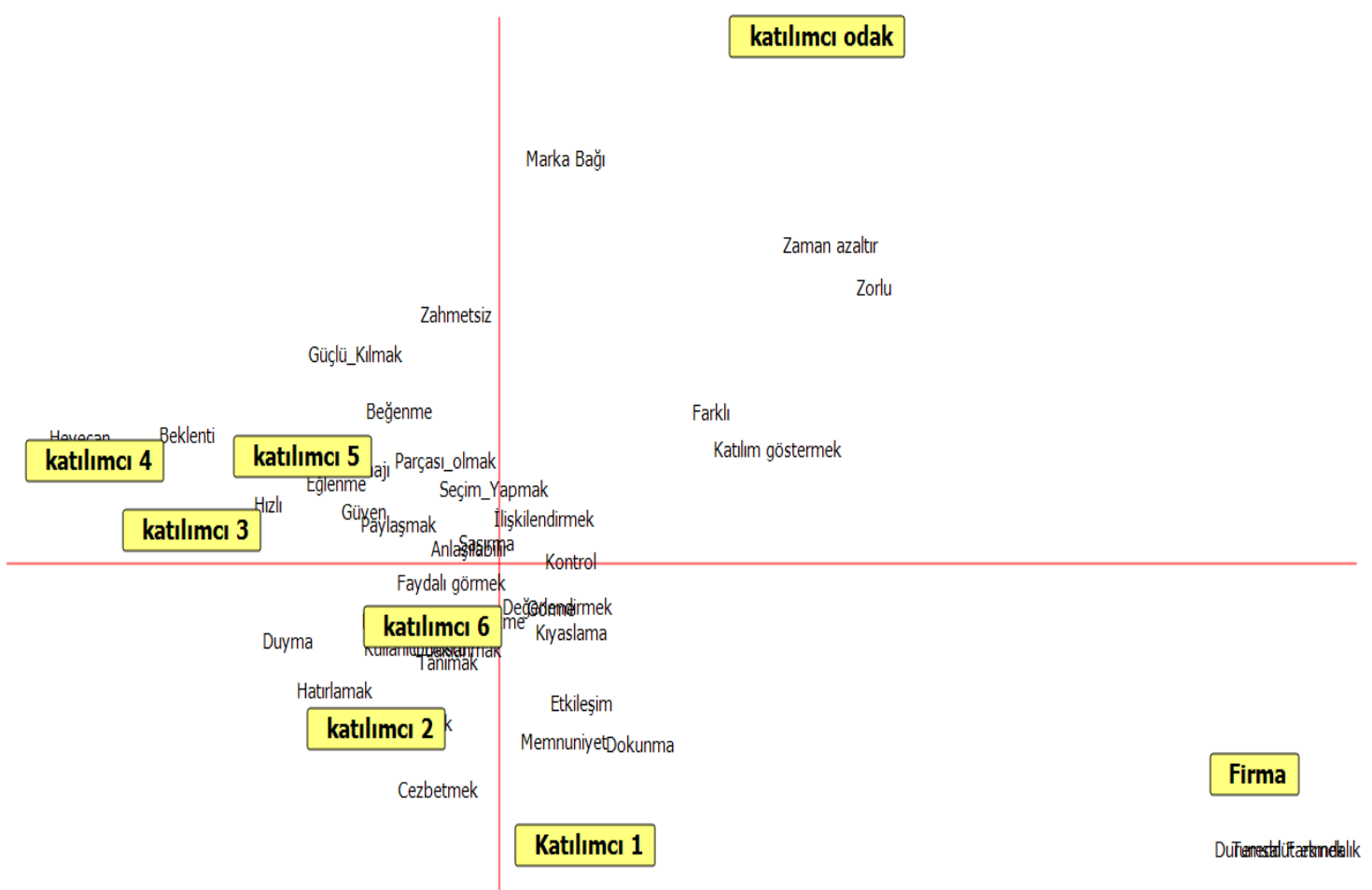

Şekil 3. Katılımcılar ve Kodlar Arası İlişki

Kod ve cinsiyet ilişkisi incelendiğinde, erkek katılımcıların tüketici deneyimine ilişkin ifadeleri, kadın katılımcıların ise satın alma niyetine ilişkin ifadeleri daha çok kullandığı saptanmıştır. Bununla birlikte, erkek katılımcıların en fazla değerlendirmeye ilişkin ifadelerde bulunduğu kadın katılımcıların ise en fazla faydalı görmeye ilişkin ifadeler kullandığı görülmüştür. Tüketici deneyimine ve çevrimiçi satın alma niyetine ilişkin kodların frekans analizinde firma yetkililerin görüşleri de dahil edilmiş ve çalışma kapsamında "betimsel analiz" yöntemiyle çalışmada ilgili yerlerde alıntılanmıştır. Tüketici ile karşılaştırması ise katılımcılar ve kodlar arası ilişki şeklinde çalışmada verilmeye çalışılmıştır.

\section{Doküman İncelemesi Analizi}

Araştırma sorusunun cevaplanmasına uygun zemin hazırladığ 1 düşünülen uygulamalar tespit edilmiş ve bunların arasından kısa sürede uygulama sonucu alınabilecek olan ve hakkında yüksek sayıda ve heterojen yorumlar barındıran bir uygulama, "amaçlı örneklem" metodu ile araştırma örneklemi olarak seçilmiştir. Çalışmada kullanılmış olan Blippar uygulamasına ilişkin Google Play Store'da yayınlanan kullanıcı yorumlarının içerik analizi yapılmıştır. İlk başta sıralanan yorumlardan anlamlı ifadeler içeren 22 farklı yorum analize dahil edilmiş̧ir. Ayrıca uygulamayı 26.410 kişinin değerlendirdiği, söz konusu değerlendirme neticesinde uygulamanın 5 üzerinden ortalama 3,5 puan aldığı görülmüsstür.

Kullanıcı yorumlarına ilişkin frekans analizi yapıldığında yorumlarda sırasıyla en çok; beğenme, kullanıcı dostu, şaşırma ve paylaşmak kodlarına ilişkin ifadelere rastlanmıştır.

Örneğin birkaç kullanıcı aşağıdaki yorumlarda bulunmuştur:

“Yok böyle bir uygulama. Çok iyi. Teknolojide daha neler göreceğiz. Muhteşem bir program”.(Kullanıc1 3) "Hiç beğenmedim amaçsız. Açılmıyor. Wifi ă̆ının yanında durduğum halde internet bağlantısını kontrol edin diyor”. (Kullanıc1 14)

“Çok güzel bir uygulama”.(Kullanıcı 19) 
Mülakat ve odak grup görüşmesinde olduğu gibi doküman incelemesi kapsamında da tüketici deneyimi ve çevrimiçi satın alma niyetine ilişkin tüketicilerin benzer ifadelerde bulunduğu görülmüştür. Özellikle duygusal deneyim, ilişkisel deneyim ve algılanan kullanışl1lık/fayda boyutlarına ilişkin görüşler yer almaktadır.

\section{Güvenirlik ve Geçerlik}

Tüketici mülakatı (EK-1) ve firma mülakatı (EK-2) soruları alanında uzman iki akademisyene gösterilmiş ve görüşleri doğrultusunda gerekli düzenlemeler yapılmıştır. Mülakat sorularından bazıları uzman görüşü doğrultusunda birleştirilmiştir. Bununla birlikte mülakat formlarının anlaşılırlığını test etmek için üç tüketiciyle ön görüşmeler yapılmıştır. Araştırmada kullanılan tema ve kodlar ilgili literatür kapsamında oluşturulmuş olup mülakat sorularına verilen cevaplar ile uyuştuğu görülmüştür.

\section{Sonuç ve Değerlendirme}

Teknoloji, tüm yaşamsal alanlarda olduğu gibi ekonomik faaliyet ve ilişkilerde de hız, güven ve konfor üretmektedir. Teknolojik gelişmelerin önemli bir uygulama alanı olan pazarlama faaliyetlerinin başarısı, yeni teknolojilerin tüketicinin ürün ve hizmetleri satın alma sürecine uyumlaştırılma kabiliyetiyle doğru orantılıdır. Artırılmış gerçeklik teknolojisi, tüketicinin çevrimiçi satın alma deneyimini, fiziksel satın alma gerçekliğine yaklaştıran, tüketiciye kişiselleştirilmiş bir ortam, zaman tasarrufu ve ürün çeşitliliği sunan önemli bir gelişme olarak görülmektedir. Artırılmış gerçekliğin pazarlama alanında giderek yoğunlaşması, söz konusu teknolojinin tüketici deneyimi ve çevrimiçi satın alma niyeti üzerindeki etkisinin ölçülmesine yönelik ihtiyacı da beraberinde getirmektedir. Bu nedenle bu çalışmada, pazarlamada artırılmış gerçeklik teknolojisi ile tüketici deneyimleri ve çevrimiçi satın alma niyeti arasındaki ilişkinin incelenmesi hedeflenmiştir.

Tüketici deneyiminin ve çevrimiçi satın alma niyetinin artırılmış gerçeklik teknolojisi ile etkileşimini ortaya koyabilmek adına çalışma kapsamında mülakat, odak grup görüşmesi ve doküman incelemesi yapılmış, elde edilen verilerin QDA Miner programı aracılığı ile içerik analizi gerçekleştirilmiş ve katılımcıların büyük çoğunluğunun bilişsel/düşünsel deneyimin bir kodu olan ve içeriğe dair tüketicilerin fikir/görüşlerini ifade eden değerlendirme koduna ilişkin ifadelerde bulunduğu görülmüştür. Bunun yanı sıra duyusal deneyimin bir kodu olan, uygulamanın ve ürünün rengi, stili, görüntü kalitesi ve resimleri gibi görünüşe ilişkin boyutlarını kapsayan görme kodunun da sıklıkla kullanıldığı tespit edilmiştir. Ayrıca bahse konu kodlardan sonra en sık kullanılan kodlar, aynı oranda olduğu tespit edilen; duygusal deneyime ilişkin şaşırma ve beğenme ile bilişsel/düşünsel deneyime ilişkin marka imajı kodları olmuştur. Bu bağlamda pazarlamada artırılmış gerçeklik uygulamalarının tüketicilerin bilişsel/düşünsel, duyusal ve duygusal deneyimleri üzerinde etkilerinin bulunduğu değerlendirilmektedir.

Katılımcıların görüşleri doğrultusunda, artırılmış gerçeklik uygulaması ile satın almaya karşı olumlu tutum sergilendiği görülmektedir. Bununla birlikte, katılımcılar tercih edecekleri satın alma yönteminde ürün türünün etkili olduğunu belirtmişlerdir. Katılımcılar ilk sırada mağazaya giderek satın almayı tercih etseler de artırılmış gerçeklik uygulaması ile satın almayı geleneksel web tabanlı satın almadan daha çok tercih 
etmişlerdir. $\mathrm{Bu}$ bağlamda artırılmış gerçekliğin markaların pazarlanmasında geleneksel yöntemlerden kısmen iyi olduğu söylenebilir. Aynı zamanda Yaoyuneyong vd. (2016) yapmış oldukları çalışmada artırılmış gerçeklik ile tasarlanmış reklamın QR kod ve geleneksel reklamlara nispeten zaman tasarrufu sağladığı sonucuna ulaşılmıştır. Bu çerçevede artırılmış gerçekliğin markaların pazarlanmasında gerek tüketici gerekse firmalar boyutunda faydalı olabileceği söylenebilir.

Tüketicilerin verdiği cevaplar doğrultusunda internetten doğrudan satın almak yerine artırılmış gerçeklik uygulamasının tercih edilmesi göz önüne alındığında, artırılmış gerçekliğin markaların tüketicilere nasıl pazarlanabileceğine dair yeni olasılıklar ortaya koyduğu sonucuna ulaşılmaktadır. Pantano ve Servidio (2012) ile Küçüksaraç ve Sayımer (2016) tarafından yapılan araştırma sonuçlarının da çalışma kapsamında elde edilen bulguları destekler nitelikte olduğu görülmektedir. Pantano ve Servidio (2012), tüketicilerin geleneksel satış noktalarında sanal ve sürükleyici teknolojilerin kullanılmasının mağazaları daha çekici hale getireceğini vurgulamaktadır. Küçüksaraç ve Sayımer (2016) araştırmaları kapsamında artırılmış gerçeklik uygulamalarının tüketiciye kişisel bir deneyim sunması, sosyal medya ortamlarında etkileşime olanak tanıması, tüketiciyi eğlendirmesi ve kişiye imaj, statü, ait olma duygusu gibi sosyal etkiler kazandırmasından dolayı diğer tanıtım faaliyetlerinden daha faydalı olabileceği sonucuna varmışlardır.

Tüketiciler çevrimiçi satın alma niyeti boyutlarından olan algılanan hizmetin kalitesine, algılanan kullanım/satın alma kolaylığına ve algılanan kullanışlılık/faydaya ilişkin yorumda bulunmuşlardır. Bu bağlamda, artırılmış gerçekliğin pazarlamada kullanılmasının tüketicilerde çevrimiçi satın alma niyeti üzerinde bir etkiye sahip olduğu görülmüştür. Kim ve Forsythe (2008) ve Bilici ve Özdemir (2019) tarafindan yapılan çalışmalarda da algılanan kullanışl11ı̆̆ın, tüketicilerin çevrimiçi giyim alışverişi için sanal denemeyi kullanmaya yönelik tutumlarında etkili olduğu sonucuna varılmıştır.

\section{Araştırmanın Katkı ve Kısıtları ile Geleceğe Yönelik Öneriler}

Çalışmanın sonuçları ışığında artıılmış gerçekliğin pazarlamada kullanılmasının, tüketicilerin çevrimiçi satın alma niyetini etkilediği görülmüştür. Literatürde bu konuda sınırlı sayıda çalışma olması bağlamında çalışmanın literatüre katkı sağlayacağı ve diğer araştırmacılar tarafından da konunun derinlemesine incelenmesinde araştırmanın yol gösterici olacağı düşünülmektedir.

Ayrıca, artırılmış gerçeklik uygulamasının pazarlamadaki ölçülen etkisi göz önüne alındığında araştırmanın, dünyada ve Türkiye'de son dönemlerde ürünlerle bütünleştirilen artırılmış gerçeklik teknolojisinin geliştirilmesine fayda sağlayacağı değerlendirilmektedir. Artırılmış gerçeklik teknolojisi, öncelikle görece sınırlı sayıda ürünle başlayan zamanla uygulaması yaygınlaşan ancak tüketicilerin henüz pazarlama alanında etkin kullanımına yeterli düzeyde aşina olmadıkları bir pazarlama stratejisi ve aracıdır. Nitekim çalışmada katılımcıların artırılmış gerçeklik uygulamasına yönelik ilk tepkileri ve uygulamanın daha önce karşılaşmamış oldukları bir teknoloji olduğunu dile getirmeleri, uygulamanın tüketim dünyasına henüz beklenen düzeyde nüfuz edemediğini göstermektedir. Ancak tüketicilerin artırılmış gerçeklik uygulamasına ilişkin deneyimlerinden varılan diğer bir sonuç da uygulamayı ürün satın almaları sırasında fayda sağlayacak, onları bilinçlendirecek, ürün karşılaştırmasına imkân sunacak şekilde yararlı görmeleridir. 
$\mathrm{Bu}$ bağlamda artırılmış gerçeklik teknolojisinin daha etkin yöntemlerle tanıtılması ve iyileştirilmesi gerekliliği araştırma kapsamındaki tüketici görüşleri doğrultusunda ortaya konulmuştur. Nitekim, yapılan mülakatlardan elde edilen sonuçlar, katılımcıların uygulamayı ilk defa tecrübe ettiklerini gösterse de uygulamanın olumlu ve gelişmeye açık yönlerini net bir şekilde ortaya koymaları çalışmanın söz konusu teknolojinin geliştirilmesi aşamasında katkı sunacağı kanısını güçlendirmektedir. Özellikle çalışmanın bulgularından cinsiyete bağlı tüketici eğilimleri ve birbiri ile ilişkili tema ve kodlar dikkate alınarak, artırılmış gerçeklik teknolojisini kullanan firmaların daha odaklı pazarlama stratejileri oluşturup geliştirebileceği düşünülmektedir. Bu çerçevede artırılmış gerçeklik teknolojisinin pazarlama alanındaki kullanımının, tüketici dönütleri dikkate alınarak gözden geçirilmesi ve geliştirilmesinin, bu teknolojinin gerek alıcılar gerekse satıcılar açısından web tabanlı geleneksel uygulamalardan daha elverişli bir araç olarak benimsenmesini sağlayacağı değerlendirilmektedir.

Araştırma, örnekleminin Ankara'da yaşayan ve düzenli geliri olan tüketicilerden oluşması sebebi ile genellenebilirlik açısından sınırlıdır. Zaman ve maddi kısıtlardan dolayı çalışmanın Ankara ilinin dışına çıkarılmasına imkân bulunamamıştır. Bu kapsamda, ilerleyen dönemde bu konuda yapılacak çalışmalarda örneklemin daha geniş belirlenmesinin yapılacak çalışmaların güvenirliğine katkıda bulunacağı öngörülmektedir. 


\section{Kaynaklar}

Avcılar, M.Y., Külter Demirgüneş, B. \& Açar, M.F. (2019). Artırılmış Gerçeklik Uygulamalarının Kullanıcı Deneyimi, Tatmin Ve Satın Alma Niyeti Üzerindeki Etkilerinin İncelenmesi. Pazarlama ve Pazarlama Araştırmaları Dergisi, 24, 235-271.

Azuma, R. T. (1997). A survey of augmented reality. Presence Teleoperators and Virtual Environments, 6(4), 355385.

Azuma, R., Baillot, Y., Behringer, R., Feiner, S., Julier, S., \& MacIntyre, B. (2001). Recent advances in augmented reality. IEEE Computer Graphics and Applications, 21(6), 34-47.

Baş, T., \& Akturan, U. (2013). Nitel araştırma yöntemleri: Nvivo ile nitel veri analizi, örnekleme, analiz (2. baskı). Ankara: Seçkin Yayınevi.

Bergeron, J. (2004). Antecedents and consequences of salesperson listening effectiveness in buyer-seller relationships (Doctoral dissertation). The John Molson School of Business, Canada.

Bilici, F. \& Özdemir, E. (2019), Tüketicilerin Artırılmış Gerçeklik Teknolojilerini Kullanmaya Yönelik Tutum ve Niyeti Üzerine Bir Araştırma. Business \& Management Studies: An Internatıonal Journal(BMIJ), 7(5), 20112033.

Bratman, M. (1987). Intention, plans, and practical reason. Cambridge, Massachusetts: Harvard University Press.

Casper, J. (2007). Sport commitment, participation frequency and purchase intention segmentation based on age, gender, income and skill level with US tennis participants. European Sport Management Quarterly, 7(3), 269282.

Chiu, C. K. (2009). Understanding relationship quality and online purchase intention in e-tourism: A qualitative application. Quality \& Quantity, 43(4), 669-675.

Claudell, T.P., \& Mizell, D. (1992). Augmented reality: An application of heads-up display technology to manual manufacturing processes. Proceedings of the Twenty-Fifth Hawaii International Conference on System Sciences, 659-669.

Close, A. G., \& Kukar-Kinney, M. (2010). Beyond buying: Motivations behind consumers' online shopping cart use. Journal of Business Research, 63(9-10), 986-992.

Dacko, S. G. (2017). Enabling smart retail settings via mobile augmented reality shopping apps. Technological Forecasting and Social Change, 124, 243-256.

Engel, J.F., Blackwell, R.D. \& Miniard, P.W. (1991). Consumer behaviour (6th ed.). USA: The Dryden Press,.

Ferrer-Garcia, M., \& Gutiérrez-Maldonado, J. (2012). The use of virtual reality in the study, assessment, and treatment of body image in eating disorders and nonclinical samples: A review of the literature. Body Image, 9(1), 111.

Flavián, C., Ibáñez-Sánchez, S., \& Orús, C. (2019). The impact of virtual, augmented and mixed reality technologies on the customer experience. Journal of Business Research, 100, 547-560.

Fornerino, M., Helme-Guizon, A. \& de Gaudemaris, C. (2006). Mesurer l'immersion dans une experience de consommation: Premiers developpements, Proceedings of the XXIIth Congress de l'AFM, Nantes.

Freitas, R., \& Campos, P. (2008). SMART: A system of augmented reality for teaching 2nd grade students. People and Computers XXII Culture, Creativity, Interaction 22, 27-30.

Gentile, C., Spiller, N., \& Noci, G. (2007). How to sustain the customer experience: An overview of experience components that co-create value with the customer. European Management Journal, 25(5), 395-410. 
Ghose, S. \& Dou, W. (1998). Interactive functions and their impacts on the appeal of internet presence sites. Journal of Advertising Research, 38(2), 29-42.

He, Z., Wu, L., \& Li, X. R. (2018). When art meets tech: The role of augmented reality in enhancing museum experiences and purchase intentions. Tourism Management, 68, 127-139.

Heijden, H. van der, Verhagen, T., \& Creemers, M. (2001). Predicting online purchase behavior: Replications and tests of competing models. Proc. 34th Hawaii Internat. Conf. System Sci., Maui, HI.

Hilken, T., de Ruyter, K., Chylinski, M., Mahr, D., \& Keeling, D. I. (2017). Augmenting the eye of the beholder: exploring the strategic potential of augmented reality to enhance online service experiences. Journal of the Academy of Marketing Science, 45(6), 884-905.

Howard, J.A., \& Sheth, J.N. (1969). The theory of buying behaviour, NY: John Wiley.

Hsu, H. Y., \& Tsou, H. T. (2011). Understanding customer experiences in online blog environments. International Journal of Information Management, 31(6), 510-523.

Hultén, B. (2011). Sensory marketing: the multi-sensory brand-experience concept. European Business Review, 23(3), 256-273.

Javornik, A. (2016). 'It's an illusion, but it looks real!' consumer affective, cognitive and behavioural responses to augmented reality applications. Journal of Marketing Management, 32(9-10), 987-1011.

Johnson, P., Buehring, A., Cassell, C., \& Symon, G. (2007). Defining qualitative management research: An empirical investigation. Qualitative Research in Organizations and Management: An International Journal, 2(1), 2342.

Kazançoğlu, İ., \& Aytekin, P. (2014). Sevgililer günü ritüellerinin alışveriş deneyimi ve hazcı alışveriş değerine etkisi: Alışveriş merkezlerinde bir uygulama. Uluslararası Yönetim İktisat ve Işsletme Dergisi, 10(22), 67-93.

Khan, H., \& Sriram, M. (2019). Role of augmented reality in influencing purchase intention among millenials. Journal of Management, 6(6).

Kim, E. Y., \& Kim, Y. K. (2004). Predicting online purchase intentions for clothing products. European Journal of Marketing, 38(7), 883-897.

Kim, J., \& Forsythe, S. (2008). Adoption of virtual try-on technology for online apparel shopping. Journal of Interactive Marketing, 22(2), 45-59.

Koufaris, M. (2002). Applying the technology acceptance model and flow theory to online consumer behavior. Information Systems Research, 13(2), 205-23.

Köse, N., \& Yengin, D. (2018). Dijital Pazarlamadan Fijital Pazarlamaya Geçişe Örnek Olarak Artırılmış Gerçeklik ve Sanal Gerçeklik Uygulamalarının Pazarlama Üzerindeki Katkılarının İncelenmesi. İstanbul Aydın Üniversitesi Dergisi, 10(1), 77-111.

Küçüksaraç, B. \& Sayımer, İ. (2016). Deneyimsel pazarlama Aracı Olarak Artırılmış Gerçeklik: Türkiye’deki Marka Deneyimlerinin Etkileri Üzerine Bir Araştırma. İstanbul Üniversitesi İletişim Fakültesi Dergisi, 51, 73-95.

LaSalle, D. \& Britton, T.A. (2003). Priceless: Turning ordinary products into extraordinary experiences. Boston: Harvard Business School Press.

Lee, K. (2012). Augmented reality in education and training. TechTrends, 56(2), 13-21.

Li, H., Daugherty, T., \& Biocca, F. (2002). Impact of 3-D advertising on product knowledge, brand attitude, and purchase intention: The mediating role of presence. Journal of Advertising, 31(3), 43-57. 
Ling, C. P., \& Ding, C. G. (2006). Evaluating group difference in gender during the formation of relationship quality and loyalty in ISP service. Journal of Organizational and End User Computing (JOEUC), 18(2), 38-62.

Mutlu, H. M., Çeviker, A., \& Çirkin, Z. (2011). Tüketici etnosentrizmi ve yabancı ürün satın alma niyeti: Türkiye ve Suriye üzerine karşılaştırmalı analiz. Sosyoekonomi, (1), 52-74.

Nicosia, F.N. (1966). Consumer decision processes. New Jersey: Prentice Hall.

Özden, A. T. (2017). Etnosentrik eğilim tüketicilerin satın alma davranışına etkisi: Doğu anadolu ve karadeniz bölgeleri üzerine karşılaştırılmalı analiz (Tez No. 4710802 [Doktora Tezi, Başkent Üniversitesi].

Pantano, E., \& Servidio, R. (2012). Modeling innovative points of sales through virtual and immersive technologies. Journal of Retailing and Consumer Services, 19(3), 279-286.

Parise, S., Guinan, P. J., \& Kafka, R. (2016). Solving the crisis of immediacy: How digital technology can transform the customer experience. Business Horizons, 59(4), 411-420.

Poushneh, A., \& Vasquez-Parraga, A. Z. (2017). Discernible impact of augmented reality on retail customer's experience, satisfaction and willingness to buy. Journal of Retailing and Consumer Services, 34, 229-234.

Rauschnabel, P. A., Felix, R., \& Hinsch, C. (2019). Augmented reality marketing: How mobile AR-apps can improve brands through inspiration. Journal of Retailing and Consumer Services, 49, 43-53.

Rauschnabel, P. A., Rossmann, A., \& Tom Dieck, M. C. (2017). An adoption framework for mobile augmented reality games: The case of Pokémon Go. Computers in Human Behavior, 76, 276-286.

Rezvani, S., Dehkordi, G. J., Rahman, M. S., Fouladivanda, F., Habibi, M., \& Eghtebasi, S. (2012). A conceptual study on the country of origin effect on consumer purchase intention. Asian Social Science, 8(12), 205-215.

Richins, M. L. (1997). Measuring emotions in the consumption experience. Journal of Consumer Research, 24, 127146.

Rosenbaum-Elliott, R., Percy, L., \& Pervan, S. (2015). Strategic brand management. USA: Oxford University Press.

Rothschild M. L. (1984). Perspectives on involvement: Current problems and future directions, Advances in Consumer Research, 11, 216-217.

Schmitt, B. (1999a). Experiential marketing. Journal of Marketing Management, 15(1-3), 53-67.

Schmitt, B. (1999b). Experiential marketing: How to get customers to sense, feel, think, act, and relate to your company and brands. New York: Free Press.

Scholz, J., \& Smith, A. N. (2016). Augmented reality: Designing immersive experiences that maximize consumer engagement. Business Horizons, 59(2), 149-161.

Shaw, C., \& Ivens, J. (2005). Building great customer experiences. NY: MacMillan.

Sığrı, Ü. (2017). Gruplarda bağllılı ve performans ilişkisi üzerine nitel bir çalışma. Uluslararası İktisadi ve İdari İncelemeler Dergisi, 481-490.

Sığrı, Ü. (2018). Nitel araştırma yöntemleri (1. Baskı). Ankara: Beta Basım Yayım Dağıtım.

Stoyanova, J., Brito, P. Q., Georgieva, P., \& Milanova, M. (2015). Comparison of consumer purchase intention between interactive and augmented reality shopping platforms through statistical analyses. 2015 International Symposium on Innovations in Intelligent SysTems and Applications (INISTA), 1-8.

Tek, Ö. B. (1999). Pazarlama ilkeleri: Global yönetimsel yaklaşım, Türkiye uygulamaları (8. Baskı). İstanbul: Beta Basım Yayım Dağıtım.

Teo, T. S. (2001). Demographic and motivation variables associated with Internet usage activities. Internet Research, 11(2), 125-137. 
Van Krevelen, D. W. F., \& Poelman, R. (2010). A survey of augmented reality technologies, applications and limitations. International Journal of Virtual Reality, 9(2), 1-20.

Verhoef, P. C., Lemon, K. N., Parasuraman, A., Roggeveen, A., Tsiros, M., \& Schlesinger, L. A. (2009). Customer experience creation: Determinants, dynamics and management strategies. Journal of Retailing, 85(1), 31-41.

Watson, A., Alexander, B., \& Salavati, L. (2018). The impact of experiential augmented reality applications on fashion purchase intention. International Journal of Retail \& Distribution Management.

Yang, Z. Y., \& He, L. Y. (2011). Goal, customer experience and purchase intention in a retail context in China: An empirical study. African Journal of Business Management, 5(16), 6738-6746.

Yaoyuneyong, G., Foster, J., Johnson, E., \& Johnson, D. (2016). Augmented reality marketing: Consumer preferences and attitudes toward hypermedia print ads. Journal of Interactive Advertising, 16(1), 16-30.

Yıldırım, A. (1999). Nitel araştırma yöntemlerinin temel özellikleri ve eğitim araştırmalarındaki yeri ve önemi. Ĕ̆itim ve Bilim, 23(112).

Yıldırım, A. \& Şimşek, H. (2008). Nitel araştırma yöntemleri. (6.Baskı). Ankara: Seçkin Yayıncılık.

Yıldırım, A., \& Şimşek, H. (2011). Sosyal bilimlerde nitel araştırma yöntemleri. Ankara: Seçkin Yayıncılık.

Ylinen, S. (2012). Consuming augmented reality marketing, a qualitative study of user experiences [Yüksek Lisans Tezi, Svenska handelshögskolan].

Zeithaml, V. A., Berry, L. L., \& Parasuraman, A. (1996). The behavioral consequences of service quality. Journal of Marketing, 60(2), 31-46. 


\section{EK-1}

Değerli Katılımc1,

\section{TÜKETICİ MÜLAKAT FORMU}

Yapacağımız bu mülakat ile artırılmış gerçeklik ile pazarlamanın tüketici deneyimi ve satın alma niyeti üzerine etkisi araştıılacaktır. Vereceğiniz cevapların doğru veya yanlış sonuçları yoktur. Önemli olan kendi bakış açınız doğrultusunda doğru olduğuna inandığınız görüşlerinizi samimi bir şekilde paylaşmanızdır. Sorulara vereceğiniz cevaplar tamamen gizli tutulacak ve üçüncü şahıslarla bilgi paylaşımı yapılmayacaktır.

\section{Mülakat için Önkoşul Sorusu:}

İnternet üzerinden ve mağazaya giderek alışveriş yapıyor musunuz?

\section{BÖLÜM 1: Giriş Sorusu}

Artırılmış gerçekliği daha önce duydunuz mu?

\section{BÖLÜM 2: Demografik Bilgiler}

Cinsiyet:

Yaşını:

Eğitiminiz:

Mesleğiniz:

BÖLÜM 3: Tüketici Deneyimi
A. Bilişsel/Düşünsel Deneyim

Deneye başlamadan önce markalar hakkındaki düşünceler sorulmaktadır.

1. Bu markaları taniyor musunuz?

2. Bu markayı görünce aklınıza gelenler nelerdir?

3. Bu markanın sizde uyandırdıkları nelerdir? Nasıl bir imajı var?

\section{Deney aşamasına geçiş}

4. İçeriği nasıl deneyimliyorsunuz?

$>$ Bu içerik nasıl düşünceleri akla getiriyor? (**Kişisel cevaplara göre daha detaylı ek sorular)

5. İçeriğe odaklanma düzeyinizi nasıl tarif edersiniz?

> Dikkatinizin daha çok içerikte mi, aygıtta mı, yoksa ikisinde de aynı anda mı toplandığını söylersiniz?

> Sizce neden ...........'a dikkat verdiniz/veremediniz?

6. Bu uygulamaları geliştiren siz olsaydınız neleri değiştirmek/eklemek veya farklı yapmak isterdiniz?

7. Uygulamada sevdiğiniz ve sevmediğiniz yanlar nelerdir?

B. Duyusal Deneyim

8. Dokunma işlevinin eklenmiş olması nasıl hissettiriyordu?

$>$ Bu tip bir dokunmatik ekran teknolojisini genel olarak nasıl deneyimliyorsunuz?

$>\mathrm{Bu}$ deneyime birden fazla duyunuzla katıldı̆̆ınızı hissediyor musunuz? Bu deneyime birden fazla duyunuzla (dokunma, görme) katılmak nasıl bir histi?

9. İçeriğin görünüşü ile ilgili ne düşünüyorsunuz?

$>$ İmgelerin kalitesini nasil tarif ederdiniz?

10. Çalan müziklerle ilgili düşünceleriniz nedir?

C. Davranışsal Deneyim

11. İçerikle etkileşim halinde olmak nasıl hissettirdi?

12. Bu tür içeriklerde bir kontrol hissinin var olduğunu hissediyor musunuz?

13. İçerikte seçimlerin yapılıyor olması sizce nasıl bir özellik?

D. Duygusal Deneyim

Bu bölümde özellikle gözlem yoluyla veri toplanmaya çalışılacaktır.

14. Böyle bir deneyim sizde ne tür duyguları uyandırdı?

E. İlişkisel Deneyim

15. Bu uygulama arkadaşlarınız/meslektaşlarınız/yaşıtlarınız ile paylaşacağınız bir şey midir?

$>$ Bu tip bir içeriği paylaşmanızı sağlayacak olan nedir?

16. Bu uygulama merak ve problem çözme duygunuzu tetiklemiş midir?

17. Uygulamadaki markaları bir kişi olarak düşünecek olursak size benzeyen yönleri var mıdır? Neden? Varsa nelerdir?

18. İçerikte yer alan markalardan herhangi birinin (birden fazla da olabilir) bu uygulamayı geliştirmesinde yer almak ister miydiniz? Hangi marka? Neden? 


\section{BÖLÜM 4: Satın Alma Niyeti}

19. Herhangi bir ürünü satın almak için böyle bir uygulamanın geliştirilmiş olmasını nasıl değerlendiriyorsunuz?

20. Bu uygulama beklentinizi karşıladı mı?

21. Bu uygulama sayesinde kolaylıkla bir ürünü satın alabileceğinizi düşünüyor musunuz?

$>$ Sizce satın alacağınız üründe böyle bir uygulamanın bulunması kolaylık sağlar mı?

$>$ Kullanıci dostu mu?

$>$ Anlaşılabilir mi?

$>$ Hizlı mı?

22. Sizce bu uygulama size kaliteli bir hizmet sunmakta midir? Neden?

23. Herhangi bir ürünü satın alma ihtimalinde artırılmış gerçeklik uygulamasını kullanmayı tercih eder misin? $>$ Neden?

$>$ Hangi ürünlerde artırılmış gerçeklik uygulamasını kullanmayı tercih edersiniz?

24. Bir ürün satın almaya niyetlendiğinizde artırılmış gerçeklik uygulaması ile mi satın almayı, artırılmış gerçeklik uygulaması kullanmadan web sitesi yoluyla mı satın almayı yoksa mağazaya giderek mi satın almayı düşünürsünüz? Neden?

\section{BÖLÜM 5: Sonuç Soruları}

25. Bu deneyim genel olarak nasıl bir histi?

$>$ Lütfen .... ile ne anlatmak istediğinizi açıklayın.

$>$ Özellikle beğendiğiniz/beğenmediğiniz bir içerik var mıydı? Lütfen nedenini belirtin.

26. Gelecekte artırılmış gerçeklik teknolojisini nerede görüyorsunuz?

27. Sonuç olarak eklemek istediğin düşünceleriniz var mı?

\section{EK-2}

\section{FİRMA MÜLAKAT FORMU}

Değerli Katılımc1,

Yapacağımız bu mülakat ile artııılmış gerçeklik ile pazarlamanın tüketici deneyimi ve satın alma niyeti üzerine etkisi araştırılacaktır. Vereceğiniz cevapların doğru veya yanlış sonuçları yoktur. Önemli olan kendi bakış açınız doğrultusunda doğru olduğuna inandığınız görüşlerinizi samimi bir şekilde paylaşmanızdır. Sorulara vereceğiniz cevaplar tamamen gizli tutulacak ve üçüncü şahıslarla bilgi paylaşımı yapılmayacaktır.

1. Artırılmış gerçeklik olgusunu ürünlerinize ne şekilde yansitıyorsunuz?

2. Hangi alanlarda artırılmış gerçeklik uygulamasını kullanıyorsunuz? Bu alanları neye göre seçiyorsunuz?

3. Artırılmış gerçeklik kullanılarak pazarlanan ürünle müşteriyi nasıl buluşturuyorsunuz?

$>$ Müssteriye hangi yöntemlerle tanıtıyorsunuz?

4. Müşteri için kullanımı kolay mı? Öncelikle bir eğitim veriyor musunuz?

5. Artırılmış gerçeklik uygulamaları hakkında müşterilerinizden ne gibi dönütler alıyorsunuz?

$>$ Tüketici deneyimi üzerine etkisi nasıll?

6. Size göre artırılmıs gerçeklik uygulamalarının tüketicinin satın alma niyetine etkisi nedir? (Etkili bir pazarlama yöntemi?)

7. İleride bu uygulamayı geliştirmeyi planlıyor musunuz? Bir yol haritanız var mı?

> Faaliyet gösterdiğiniz alandan bağımsız olarak başka hangi alanlarda kullanılabileceğini düşünüyorsunuz? Eklemek istediğiniz bir şey var mı? 